\title{
Greenhouse gases emissions from riparian wetlands: an example from the Inner Mongolia grassland region in China
}

\author{
Xinyu Liu ${ }^{1,2}$, Xixi Lu ${ }^{1,3}$, Ruihong Yu${ }^{1,2}$, Heyang Sun ${ }^{1}$, Hao Xue ${ }^{1}$, Zhen Qi ${ }^{1}$, Zhengxu Cao ${ }^{1}$, Zhuangzhuang Zhang ${ }^{1}$, \\ and Tingxi Liu $^{4}$ \\ ${ }^{1}$ Inner Mongolia Key Laboratory of River and Lake Ecology, School of Ecology and Environment, \\ Inner Mongolia University, Hohhot 010021, China \\ ${ }^{2}$ Key Laboratory of Mongolian Plateau Ecology and Resource Utilization, Ministry of Education, Hohhot 010021, China \\ ${ }^{3}$ Department of Geography, National University of Singapore, 117570, Singapore \\ ${ }^{4}$ Inner Mongolia Water Resource Protection and Utilization Key Laboratory, Water Conservancy and \\ Civil Engineering College, Inner Mongolia Agricultural University, Hohhot 010021, China
}

Correspondence: Ruihong Yu (rhyu@imu.edu.cn) and Tingxi Liu (txliu@imau.edu.cn)

Received: 22 May 2020 - Discussion started: 28 July 2020

Revised: 22 June 2021 - Accepted: 29 July 2021 - Published: 1 September 2021

\begin{abstract}
Gradual riparian wetland drying is increasingly sensitive to global warming and contributes to climate change. Riparian wetlands play a significant role in regulating carbon and nitrogen cycles. In this study, we analyzed the emissions of carbon dioxide $\left(\mathrm{CO}_{2}\right)$, methane $\left(\mathrm{CH}_{4}\right)$, and nitrous oxide $\left(\mathrm{N}_{2} \mathrm{O}\right)$ from riparian wetlands in the Xilin River basin to understand the role of these ecosystems in greenhouse gas (GHG) emissions. Moreover, the impact of the catchment hydrology and soil property variations on GHG emissions over time and space was evaluated. Our results demonstrate that riparian wetlands emit larger amounts of $\mathrm{CO}_{2}\left(335-2790 \mathrm{mg} \mathrm{m}^{-2} \mathrm{~h}^{-1}\right.$ in the wet season and 72$387 \mathrm{mg} \mathrm{m}^{-2} \mathrm{~h}^{-1}$ in the dry season) than $\mathrm{CH}_{4}$ and $\mathrm{N}_{2} \mathrm{O}$ to the atmosphere due to high plant and soil respiration. The results also reveal clear seasonal variations and spatial patterns along the transects in the longitudinal direction. $\mathrm{N}_{2} \mathrm{O}$ emissions showed a spatiotemporal pattern similar to that of $\mathrm{CO}_{2}$ emissions. Near-stream sites were the only sources of $\mathrm{CH}_{4}$ emissions, while the other sites served as sinks for these emissions. Soil moisture content and soil temperature were the essential factors controlling GHG emissions, and abundant aboveground biomass promoted the $\mathrm{CO}_{2}, \mathrm{CH}_{4}$, and $\mathrm{N}_{2} \mathrm{O}$ emissions. Moreover, compared to different types of grasslands, riparian wetlands were the potential hotspots of GHG emissions in the Inner Mongolian region. Degradation of downstream wetlands has reduced the soil carbon pool by approximately $60 \%$, decreased $\mathrm{CO}_{2}$ emissions by approx-
\end{abstract}

imately $35 \%$, and converted the wetland from a $\mathrm{CH}_{4}$ and $\mathrm{N}_{2} \mathrm{O}$ source to a sink. Our study showed that anthropogenic activities have extensively changed the hydrological characteristics of the riparian wetlands and might accelerate carbon loss, which could further affect GHG emissions.

\section{Introduction}

With the increasing rate of global warming, the change in the concentrations of greenhouse gases (GHGs) in the atmosphere is a source of concern in the scientific community (Cao et al., 2005). According to the World Meteorological Organization (WMO, 2018), the concentrations of carbon dioxide $\left(\mathrm{CO}_{2}\right)$, methane $\left(\mathrm{CH}_{4}\right)$, and nitrous oxide $\left(\mathrm{N}_{2} \mathrm{O}\right)$ in the atmosphere have increased by $146 \%, 257 \%$, and $122 \%$, respectively, since 1750 . Despite their lower atmospheric concentrations, $\mathrm{CH}_{4}$ and $\mathrm{N}_{2} \mathrm{O}$ absorb infrared radiation approximately 28 and 265 times more effectively at centennial timescales than $\mathrm{CO}_{2}$ (IPCC, 2013), respectively. On a global scale, $\mathrm{CO}_{2}, \mathrm{CH}_{4}$, and $\mathrm{N}_{2} \mathrm{O}$ together are responsible for $87 \%$ of the GHG effect (Ferrón et al., 2007).

Wetlands are unique ecosystems that serve as transition zones between terrestrial and aquatic ecosystems. They play an important role in the global carbon cycle (Beger et al., 2010; Naiman and Decamps, 1997). Wetlands are sensitive to hydrological changes, particularly in the context of global 
climate change (Cheng and Huang, 2016). Moreover, wetland hydrology is affected by local anthropogenic activities, such as the construction of reservoirs, resulting in gradual drying. Although wetlands cover only $4 \%-6 \%$ of the terrestrial land surface, they contain approximately $12 \%-24 \%$ of global terrestrial soil organic carbon (SOC), thus acting as carbon sinks. Moreover, they release $\mathrm{CO}_{2}, \mathrm{CH}_{4}$, and $\mathrm{N}_{2} \mathrm{O}$ into the atmosphere and serve as carbon sources ( $\mathrm{Lv}$ et al., 2013). During plant photosynthesis, the amount of carbon accumulated is generally higher than the amount of $\mathrm{CO}_{2}$ consumed (plant respiration, animal respiration, and microbial decomposition) in the wetland; thus, the net effect of the wetland is that of a carbon sink. Wetlands are increasingly recognized as an essential part of nature, given their simultaneous functions as carbon sources and sinks. Excessive rainfall causes an expansion in wetland area and a sharp increase in soil moisture content, thus enhancing respiration, methanogenesis, nitrification, and denitrification rates (Mitsch et al., 2009). On the other hand, reduced precipitation or severe droughts decrease water levels, causing the wetlands to dry up. The accumulated carbon is released back into the atmosphere through oxidation. Due to the increasing impact of climate change and human activity, drying of wetlands has been widely observed in recent years (Liu et al., 2006); more than half of global wetlands have disappeared since 1900 (Mitsch and Gosselink, 2007), and this tendency is expected to continue in the future. The loss of wetlands may directly shift the soil environment from anoxic to oxic conditions, while modifying the $\mathrm{CO}_{2}$ and $\mathrm{CH}_{4}$ source and sink functions of wetland ecological systems (Waddington and Roulet, 2000; Zona et al., 2009).

The Xilin River basin in China is characterized by a marked spatial gradient in soil moisture content. It is a unique natural laboratory that may be used to explore the close relationships between the spatiotemporal variations in hydrology and riparian biogeochemistry. Wetlands around the Xilin River play an irreplaceable role with regard to local climate control, water conservation, the carbon and nitrogen cycles, and husbandry (Gou et al., 2015; Kou, 2018). Moreover, the Xilin River region is subjected to seasonal alterations in precipitation and temperature regimes. Construction of the Xilin River reservoir has resulted in highly negative consequences, such as the drying of downstream wetlands, thereby affecting riparian hydrology and microbial activity in riparian soils. GHG emissions in riparian wetlands vary immensely. Therefore, understanding the interactions between the GHG emissions and hydrological changes in the Xilin River riparian wetlands has become increasingly important. Moreover, it is necessary to estimate the changes in GHG emissions as a result of wetland degradation at local and global scales.

In this work, GHG emissions from riparian wetlands and adjacent hillslope grasslands of the Xilin River basin were investigated. GHG emissions, soil temperature, and soil moisture content were measured in the dry and wet seasons. The main objectives of this study were to (1) investigate the tem- poral and spatial variations in $\mathrm{CO}_{2}, \mathrm{CH}_{4}$, and $\mathrm{N}_{2} \mathrm{O}$ emissions from the wetlands in the riparian zone and examine the main factors affecting the GHG emissions; (2) compare the GHG emissions from the riparian wetlands with those from different types of grasslands; and (3) evaluate the impact of wetland degradation in the study area on GHG emissions.

\section{Materials and methods}

\subsection{Study site}

The Xilin River is situated in the southeastern part of the Inner Mongolia Autonomous Region in China $\left(43^{\circ} 26^{\prime}-\right.$ $44^{\circ} 39^{\prime} \mathrm{N}, 115^{\circ} 00^{\prime}-117^{\circ} 30^{\prime} \mathrm{E}$ ). It is a typical inland river of the Inner Mongolia grasslands. The river basin area is $10542 \mathrm{~km}^{2}$, total length is $268.1 \mathrm{~km}$, and average altitude is $988.5 \mathrm{~m}$. According to the meteorological data provided by the Xilinhot Meteorological Station (Xi et al., 2017; Tong et al., 2004), the long-term annual mean air temperature is $1.7^{\circ} \mathrm{C}$, and the maximum and minimum monthly means are $20.8^{\circ} \mathrm{C}$ in July and $-19.8^{\circ} \mathrm{C}$ in January, respectively. The average annual precipitation was $278.9 \mathrm{~mm}$ for the period of 1968-2015. Precipitation is distributed unevenly among the seasons, with $87.41 \%$ of the total precipitation occurring between May and September.

Soil types in the Xilin River basin are predominantly chernozems $(86.4 \%)$, showing a significant zonal distribution as light chestnut soil, dark chestnut soil, and chernozems from the northwest to southeast. Soil types in this basin also present a vertical distribution with elevation. Soluble chernozems and carbonate chernozems are primarily observed at altitudes above $1350 \mathrm{~m}$, with a relatively fertile and deep soil layer. Dark chestnut soil, boggy soil, and dark meadow with high humus content are distributed between the altitudes of 1150 and $1350 \mathrm{~m}$. Meanwhile, light chestnut soil, saline meadow soil, and meadow solonchak with low soil humus, a thin soil layer, and coarse soil texture are distributed between the altitudes of 902 and $1150 \mathrm{~m}$ above sea level (Xi et al., 2017).

\subsection{Field measurements and laboratory analyses}

In this study, five representative transects were selected as the primary measurement sites in the entire Xilin River. Each transect cuts through the riparian wetlands near the river and the hillslope grasslands further away (Fig. 1).

The layout of the sampling points of each transect is shown in Fig. 2. Each sampling point, from T1-T5, was extended from either side of the river to the grassland on the slopes by using five to seven sampling points for each transect, resulting in 24 points in total. The sampling sites on the left and right banks were defined as L1-L3 and R1-R4 from the riparian wetlands to the hillslope grasslands. As transect T3 was located on a much wider flood plain, none of its sampling points were located on the hillslope grassland. The last 


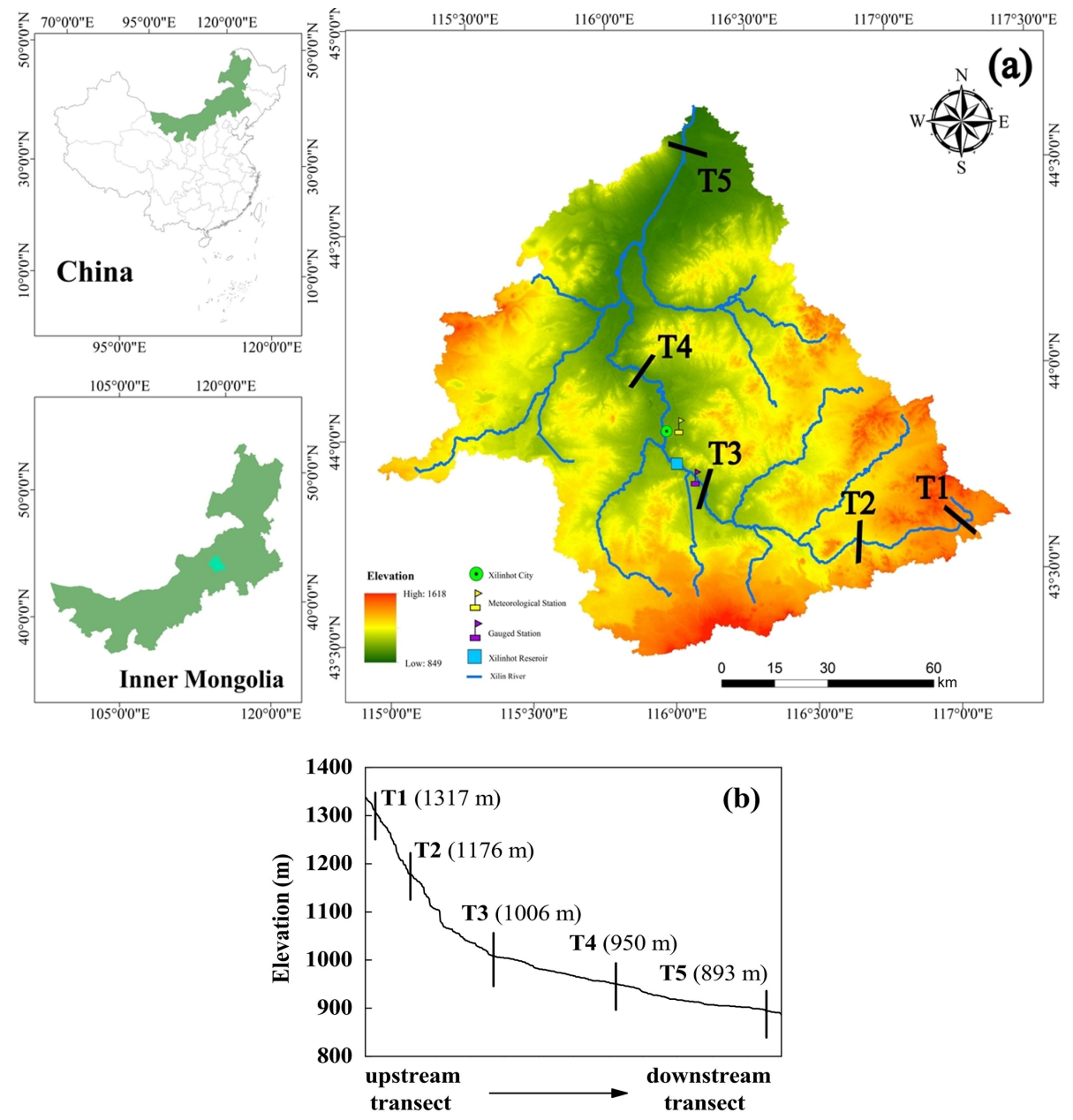

Figure 1. (a) Location of the Xilin River basin and distribution of five riparian-hillslope transects (T1-T5). (b) Elevation details of each transect in the Xilin River basin.

transect (T5) was located downstream in the dry lake and contained seven sampling points. They were defined as S1S7, where S1, S2, and S7 were located along the lakeshore (the lakeside zone), and S3-S6 were located in the dry lake bed (S3 and S4 in the mudbank, S5 in saline-alkali soil, and S6 in sand-gravel geology). Moreover, characterizations for the $\mathrm{T} 1, \mathrm{~T} 2$, and $\mathrm{T} 3$ transects were located along the continuous river flow, and the T4 and T5 transects were located along the intermittent river flow.

The $\mathrm{CO}_{2}, \mathrm{CH}_{4}$, and $\mathrm{N}_{2} \mathrm{O}$ emissions from each site were measured in August (wet season) and October (dry season) in 2018 using a static dark chamber and the gas chromatography method. The static chambers were made of a cubeshaped polyvinyl chloride (PVC) pipe (dimensions: $0.4 \mathrm{~m} \times$ $0.2 \mathrm{~m} \times 0.2 \mathrm{~m}$ ). A battery-driven fan was installed horizontally inside the top wall of the chamber to ensure proper air mixing during measurements. To minimize heating from solar radiation, white adiabatic aluminum foil was used to cover the entire aboveground portion of the chamber. During measurements, the chambers were driven into the soil to ensure airtightness and connected with a differential gas analyzer ( $\mathrm{Li}-7000 \mathrm{CO}_{2} / \mathrm{H}_{2} \mathrm{O}$ analyzer, LI-COR, USA) to measure the changes in the soil $\mathrm{CO}_{2}$ concentration. The air in the chamber was sampled using a $60 \mathrm{~mL}$ syringe at 0,7 , 14,21 , and $28 \mathrm{~min}$. The gas samples were stored in a reservoir bag and taken to the laboratory for $\mathrm{CH}_{4}$ and $\mathrm{N}_{2} \mathrm{O}$ measurements using gas chromatography (GC-2030, Japan). The measurements were scheduled for 09:00-11:00 or 15:0017:00 UTC +8 .

Soil temperature (ST) was measured at depths of $0-10$ and 10-20 cm with a geothermometer (DTM-461, Hengshui, China). Plant samples were collected in a static chamber and oven-dried in the laboratory to obtain aboveground biomass (BIO). A $100 \mathrm{~cm}^{3}$ ring cutter was used to collect surface soil samples at each site, which were placed in aluminum boxes and immediately brought back to the laboratory to measure soil mass moisture content (SMC) and soil bulk density $\left(\rho_{\mathrm{b}}\right)$ using national standard methods (NATESC, 2006). Topsoil samples were collected, sealed in plastic bags, and brought back to the laboratory to measure soil $\mathrm{pH}$, electrical conduc- 

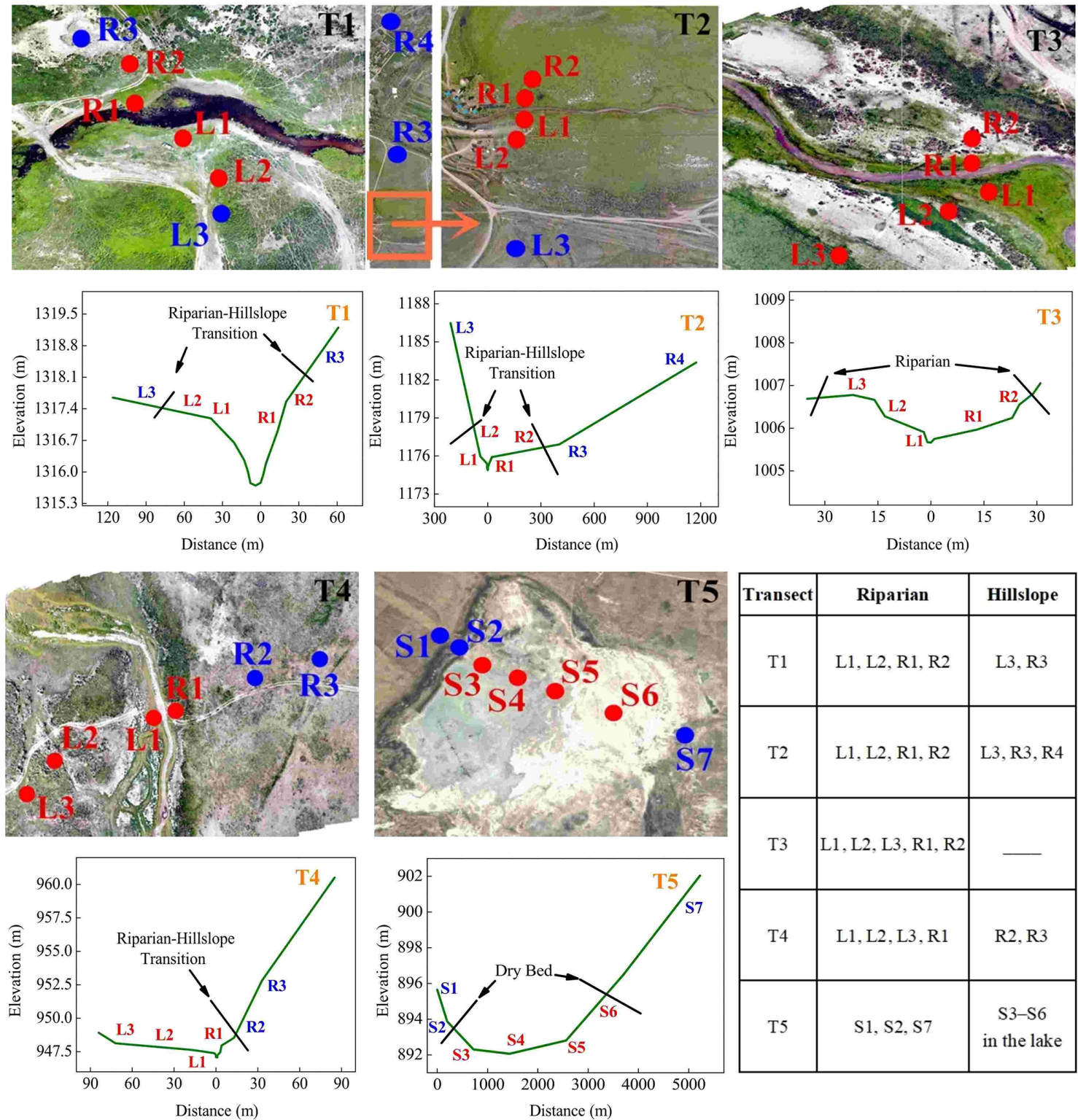

\begin{tabular}{|c|c|c|}
\hline T1 & L1, L2, R1, R2 & L3, R3 \\
\hline T2 & L1, L2, R1, R2 & L3, R3, R4 \\
\hline T3 & L1, L2, L3, R1, R2 & - \\
\hline T4 & L1, L2, L3, R1 & R2, R3 \\
\hline T5 & S1, S2, S7 & $\begin{array}{c}\text { S3-S6 } \\
\text { in the lake }\end{array}$ \\
\hline
\end{tabular}

Figure 2. Distributions of sampling points in transects T1-T5 (the images are the authors' own).

tivity (EC), total soil organic carbon (TOC) content, and soil $\mathrm{C}: \mathrm{N}$ ratio.

\subsection{Calculation of GHG emissions}

The $\mathrm{CO}_{2}, \mathrm{CH}_{4}$, and $\mathrm{N}_{2} \mathrm{O}$ emissions were calculated using Eq. (1) (Qin et al., 2016):

$F=\frac{V}{A} \times \frac{\mathrm{d} c}{\mathrm{~d} t} \times \rho=H \times \frac{\mathrm{d} c}{\mathrm{~d} t} \times \frac{M}{V} \times\left(\frac{273.15}{273.15+t}\right)$,

where $F$ denotes the flux of $\mathrm{CO}_{2}, \mathrm{CH}_{4}$, and $\mathrm{N}_{2} \mathrm{O}$ emissions $\left(\mathrm{mg} \mathrm{m}^{-2} \mathrm{~h}^{-1}\right) ; H$ is the height of the static chamber $(0.18 \mathrm{~m})$; $M$ is the relative molecular weight (44 for $\mathrm{CO}_{2}$ and $\mathrm{N}_{2} \mathrm{O}$, and 16 for $\mathrm{CH}_{4}$ ); $V$ is the volume of gas in the standard state $\left(22.4 \mathrm{~L} \mathrm{~mol}^{-1}\right) ; \mathrm{d} c / \mathrm{d} t$ is the rate of change of the gas concentration $\left(10^{-6} \mathrm{~h}^{-1}\right)$; and $T$ is the temperature in the black chamber $\left({ }^{\circ} \mathrm{C}\right)$.

The annual cumulative emissions were calculated using Eq. (2) (Whiting and Chanton, 2001):

$M=\sum \frac{F_{i+1}+F_{1}}{2} \times\left(t_{i+1}-t_{i}\right) \times 24$,

where $M$ denotes the total cumulative emission amounts of $\mathrm{CO}_{2}, \mathrm{CH}_{4}$, or $\mathrm{N}_{2} \mathrm{O}\left(\mathrm{kg} \mathrm{hm}^{2}\right) ; F$ is the emission flux of $\mathrm{CO}_{2}$, $\mathrm{CH}_{4}$, or $\mathrm{N}_{2} \mathrm{O} ; i$ is the sampling frequency; and $t_{i+1}-t_{i}$ represents the interval between two adjacent measurement dates.

In this study, a 100-year timescale was selected to calculate the global warming potential (GWP) of soil $\mathrm{CH}_{4}$ and 


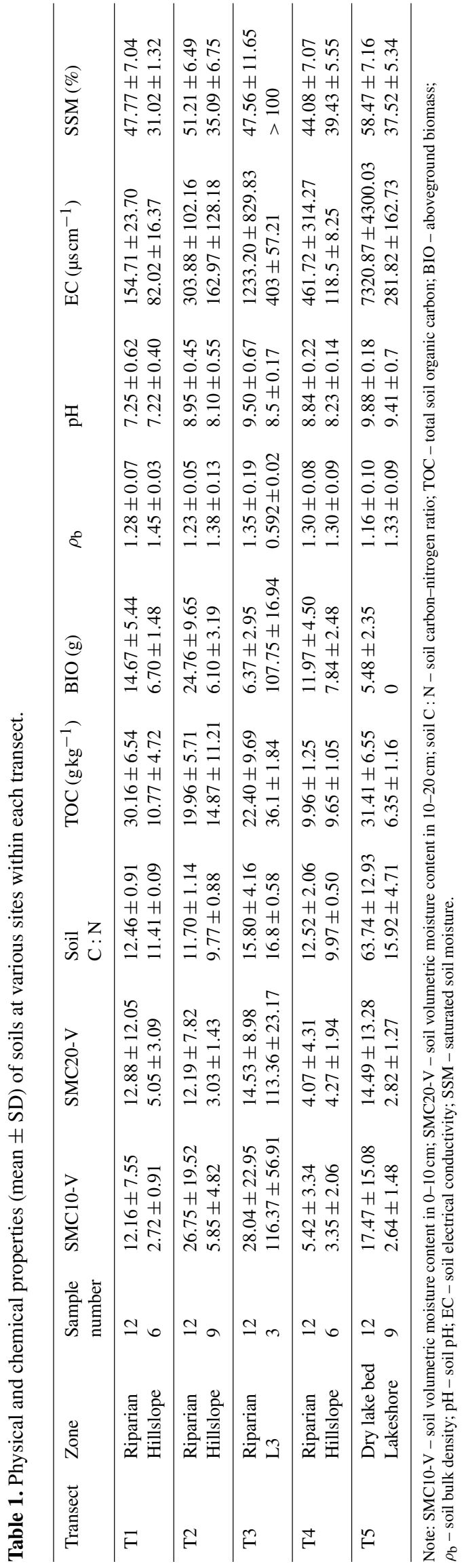

$\mathrm{N}_{2} \mathrm{O}$ emissions (Whiting and Chanton, 2001):

$\mathrm{GWP}=1 \times\left[\mathrm{CO}_{2}\right]+25 \times\left[\mathrm{CH}_{4}\right]+298 \times\left[\mathrm{N}_{2} \mathrm{O}\right]$,

where 25 and 298 are the GWP multiples of $\mathrm{CH}_{4}$ and $\mathrm{N}_{2} \mathrm{O}$ relative to $\mathrm{CO}_{2}$ on a 100 -year timescale, respectively.

\subsection{Statistical analysis}

All statistical analyses were performed using SPSS for Windows version 18.0 (SPSS Inc., Chicago, IL, USA). Statistical significance was set at $P<0.05$. Pearson correlation analysis was conducted to estimate the relationships between GHG fluxes and environmental variables. A Wilcoxon test was used to determine the differences in the GHG fluxes between the two seasons.

\section{Results}

\subsection{Spatiotemporal patterns of SMC for each transect}

The temporal and spatial variations in SMC10 occurred in the following order: wet season $>$ dry season and riparian wetlands $>$ hillslope grasslands (Fig. 3a, c, and e). Similar variations were observed in SMC20 (Fig. 3b, d, and f). The average SMC10 and SMC20 in the continuous river transects in the riparian zones (SMC10 values were $37.44 \%$ in the wet season and $19.40 \%$ in the dry season, while SMC20 values were $25.96 \%$ in the wet season and $17.39 \%$ in the dry season) were higher than those in the hillslope grasslands (SMC10 values were $9.12 \%$ in the wet season and $4.15 \%$ in the dry season; SMC20 values were $6.51 \%$ in the wet season and $5.96 \%$ in the dry season). During the study period, both SMC10 and SMC20 changed as the distance from the river increased, and the highest value was observed at the near-stream sites (L1 and R1). SMC10 fluctuations were low in the intermittent transect compared with those in the upstream transects, with mean values being $11.79 \%$ in the wet season and $3.72 \%$ in the dry season in the riparian areas. The mean SMC10 in the hillslopes was $6.58 \%$ in the wet season and $2.86 \%$ in the dry season. SMC20 showed similar fluctuation; it was $7.22 \%$ in the wet season and $2.98 \%$ in the dry season in the riparian areas and $7.56 \%$ in the wet season and $4.4 \%$ in the dry season in the hillslopes. In transect T5, average SMC10 and SMC20 at the center of the lake (SMC10 values were $29.00 \%$ in the wet season and $13.36 \%$ in the dry season; SMC20 values were $29.30 \%$ in the wet season and $9.69 \%$ in the dry season) were higher than those along the lakeshore (SMC10 values were $4.90 \%$ in the wet season and $3.13 \%$ in the dry season; SMC20 values were $3.34 \%$ in the wet season and $5.22 \%$ in the dry season).

\subsection{Spatiotemporal patterns of ST in each transect}

Spatiotemporal differences in ST during the entire observation period are displayed in Fig. 4. ST variations in the wet 
Table 2. Soil particle composition of soils at various sites within each transect.

\begin{tabular}{llrrr}
\hline Transect & Zone & \multicolumn{3}{c}{ Soil particle composition } \\
\cline { 3 - 5 } & & $\begin{array}{r}\text { Clay \% } \\
(<0.002 \mathrm{~mm})\end{array}$ & $\begin{array}{r}\text { Silt } \% \\
(0.02-0.002 \mathrm{~mm})\end{array}$ & $\begin{array}{r}\text { Sand } \\
(2.0-0.02 \mathrm{~mm})\end{array}$ \\
\hline $\mathrm{T} 1$ & Riparian & 2.5 & 2.7 & 94.8 \\
& Hillslope & 9.6 & 6.1 & 85.3 \\
\hline $\mathrm{T} 2$ & Riparian & 5.5 & 5.8 & 90.7 \\
& Hillslope & 10.8 & 8.6 & 80.6 \\
\hline $\mathrm{T} 3$ & Riparian & 4.1 & 1.1 & 94.8 \\
\hline $\mathrm{T} 4$ & Riparian & 11.4 & 1.5 & 87.1 \\
& Hillslope & 12.7 & 5.9 & 81.4 \\
\hline T5 & Lakeshore & 5.1 & 2.1 & 92.8 \\
& Dry lake bed & 46.1 & 4.8 & 49.1 \\
\hline
\end{tabular}

season (mean was $27.4^{\circ} \mathrm{C}$ ) were noticeably higher than those in the dry season (mean was $8.97^{\circ} \mathrm{C}$ ). Moreover, ST at riparian sites (mean, $26.0^{\circ} \mathrm{C}$ in the wet season and $8.41^{\circ} \mathrm{C}$ in the dry season) was slightly lower than that at the hillslope grasslands (mean, $30.9^{\circ} \mathrm{C}$ in the wet season and $10.3{ }^{\circ} \mathrm{C}$ in the dry season) for the $0-10 \mathrm{~cm}$ soil depth, with the exception of transect T5. Similar results were observed for the $10-20 \mathrm{~cm}$ soil depth.

\subsection{Spatiotemporal patterns of GHG emissions in each transect}

Figure 5 shows the spatiotemporal variations in GHG emissions in the wet and dry seasons in each transect. $\mathrm{CO}_{2}$ emissions in each transect were higher in the wet season than in the dry season. The average emissions in the riparian wetland transects T1-T4 $\left(1582.09 \pm 679.34 \mathrm{mg} \mathrm{m}^{-2} \mathrm{~h}^{-1}\right.$ in the wet season and $163.24 \pm 84.98 \mathrm{mg} \mathrm{m}^{-2} \mathrm{~h}^{-1}$ in the dry season) were higher than the transects in the hillslope grasslands $\left(1071.54 \pm 225.39 \mathrm{mg} \mathrm{m}^{-2} \mathrm{~h}^{-1}\right.$ in the wet season and $77.68 \pm 25.32 \mathrm{mg} \mathrm{m}^{-2} \mathrm{~h}^{-1}$ in the dry season). High $\mathrm{CO}_{2}$ fluxes occurred in the riparian zones, while lower $\mathrm{CO}_{2}$ fluxes were observed in the hillslope grasslands in continuous river transects (T1, T2, and T3). Transect T4 exhibited lower $\mathrm{CO}_{2}$ emission in the riparian wetlands near the channel than at sites away from the channel. $\mathrm{CO}_{2}$ emissions in transect $\mathrm{T} 5 \mathrm{in}$ the wet and dry seasons decreased from the lakeshore to the lake center.

$\mathrm{CH}_{4}$ emissions at the continuous river flow transects ( $\mathrm{T}$, T2, and T3) varied between the wet and dry seasons, except for those at $\mathrm{T} 4$ (characterized by intermittent river flow) and T5 (the dry lake). In the wet season, the near-stream sites (L1 and R1) in T1, T2, and T3 were characterized as high- $\mathrm{CH}_{4}$ sources (average, $3.74 \pm 3.81 \mathrm{mg} \mathrm{m}^{-2} \mathrm{~h}^{-1}$ ), but the sites located away from the river gradually turned into $\mathrm{CH}_{4}$ sinks. Moreover, all the sites in transects $\mathrm{T} 4$ and $\mathrm{T} 5$ were sinks. $\mathrm{CH}_{4}$ emissions (mean value: $0.2 \pm 0.45 \mathrm{mg} \mathrm{m}^{-2} \mathrm{~h}^{-1}$ ) at the wetland sites were always lower in the dry season than those in the wet season. However, the sites on the hillslope grasslands served as $\mathrm{CH}_{4}$ sinks (mean value: $-0.05 \pm$ $0.03 \mathrm{mg} \mathrm{m}^{-2} \mathrm{~h}^{-1}$ ). In transect $\mathrm{T} 5, \mathrm{CH}_{4}$ emissions showed the opposite trend; a $\mathrm{CH}_{4}$ sink was observed in the wet season, but it was transformed into a $\mathrm{CH}_{4}$ source in the dry season.

Similar to the $\mathrm{CO}_{2}$ and $\mathrm{CH}_{4}$ emissions, $\mathrm{N}_{2} \mathrm{O}$ emissions showed a distinct spatiotemporal pattern in all the transects. $\mathrm{N}_{2} \mathrm{O}$ emissions in the wet season were higher than those in the dry season. These emissions were higher in the riparian wetlands than in the hillslope grasslands. Moreover, almost all sites with continuous river flow were $\mathrm{N}_{2} \mathrm{O}$ sources, while more than half of the sites with intermittent river flow were sinks.

Table 3 shows that $\mathrm{CO}_{2}$ fluxes were significantly correlated between the wet and dry seasons, while $\mathrm{CH}_{4}$ and $\mathrm{N}_{2} \mathrm{O}$ fluxes were not correlated between the two seasons.

\subsection{Spatiotemporal patterns of GHG emission in upstream and downstream areas}

Figure 6 shows the detailed spatial and seasonal patterns of GHG emission in the wet and dry seasons in the longitudinal direction from the upstream (T1, T2, and T3) to the downstream areas (T4 and T5). The $\mathrm{CO}_{2}, \mathrm{CH}_{4}$, and $\mathrm{N}_{2} \mathrm{O}$ emissions were calculated using the average values of the respective emissions in the wetlands and hillslope grasslands in each transect.

$\mathrm{CO}_{2}$ emissions at the riparian wetlands (Fig. 6a) in the wet season decreased from $2444.69 \pm 228.58 \mathrm{mg} \mathrm{m}^{-2} \mathrm{~h}^{-1}$ in the upstream area to $665.08 \pm 347.57 \mathrm{mg} \mathrm{m}^{-2} \mathrm{~h}^{-1}$ downstream, and the corresponding values for the dry season were $238.12 \pm 48.20$ and $94.14 \pm 7.67 \mathrm{mg} \mathrm{m}^{-2} \mathrm{~h}^{-1}$, respectively. However, in the hillslope grasslands (Fig. 6b), $\mathrm{CO}_{2}$ emissions exhibited no significant seasonality between the upstream and downstream areas, with mean values being $1103.40 \pm 190.44 \mathrm{mg} \mathrm{m}^{-2} \mathrm{~h}^{-1}$ in the wet season and 
Wet season
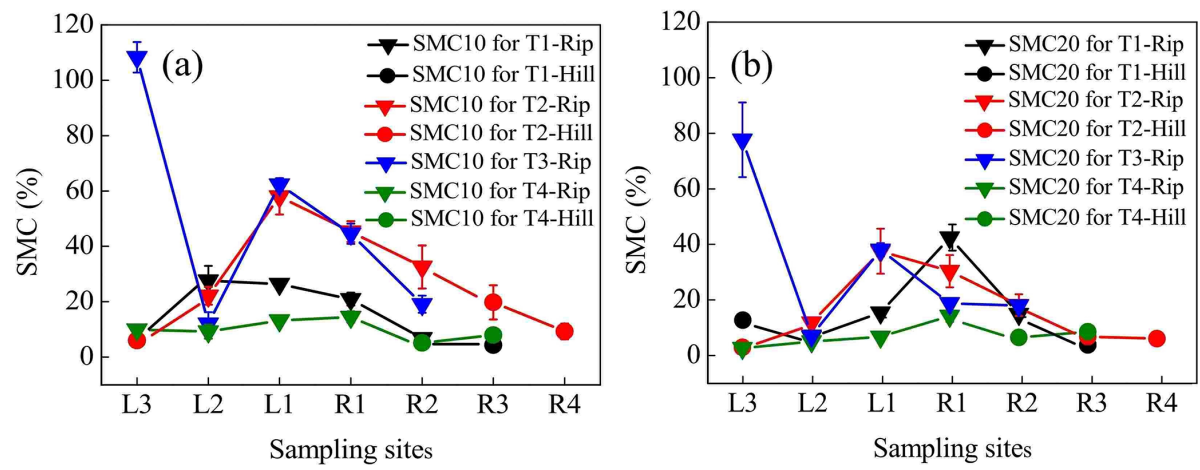

Dry season
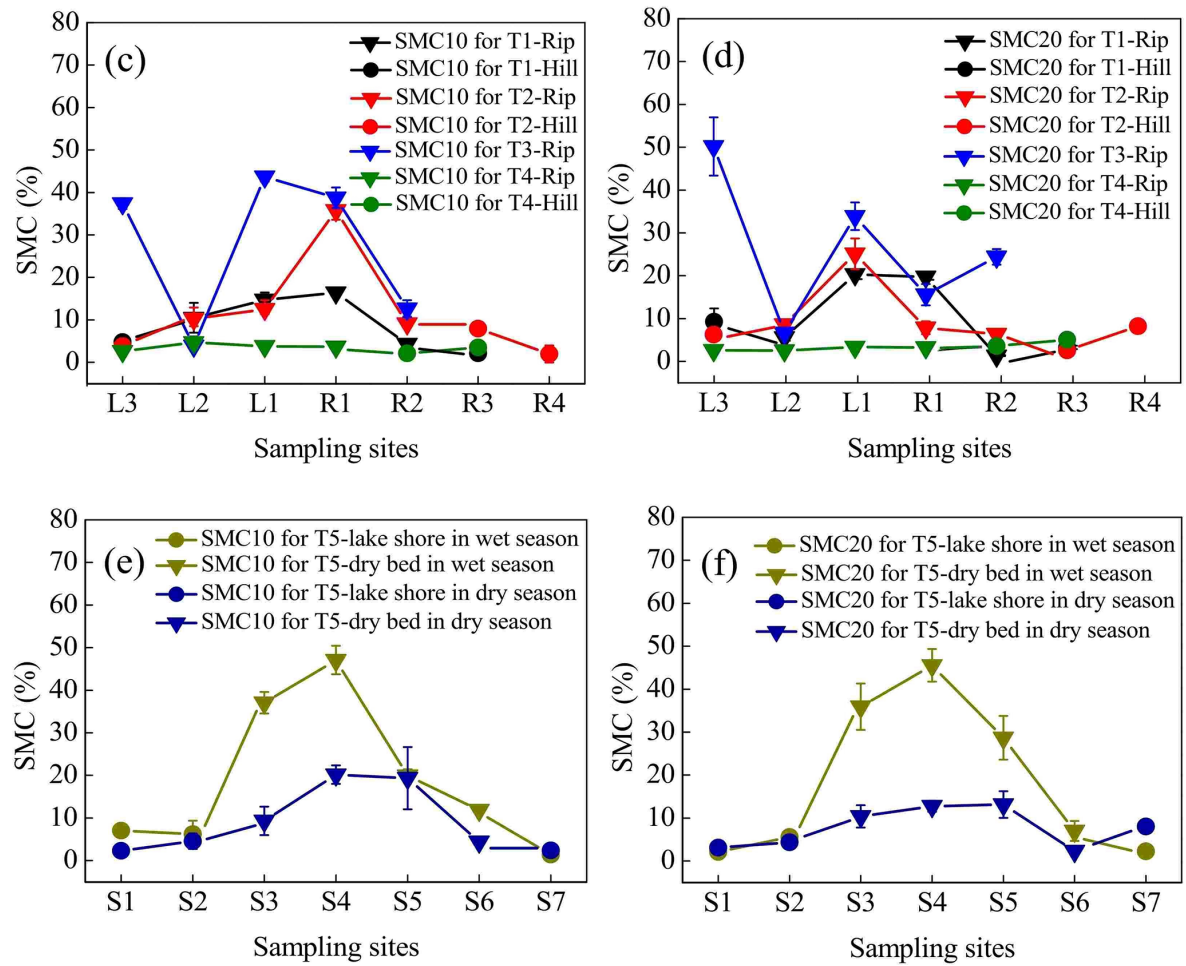

Figure 3. Soil mass moisture contents (SMCs) at soil depths of 0-10 cm (SMC10) and 10-20 cm (SMC20) for transects T1-T5 in the wet and dry seasons. Error bars represent the SD about the mean.

$79.18 \pm 24.52 \mathrm{mg} \mathrm{m}^{-2} \mathrm{~h}^{-1}$ in the dry season. In addition, the $\mathrm{CO}_{2}$ emissions in transect T5 were low for both months, with averages of $162.83 \pm 149.15 \mathrm{mg} \mathrm{m}^{-2} \mathrm{~h}^{-1}$ and $63.26 \pm$ $12.40 \mathrm{mg} \mathrm{m}^{-2} \mathrm{~h}^{-1}$ in the wet and dry seasons, respectively. The upstream riparian zones exhibited higher $\mathrm{CO}_{2}$ emissions $\left(894.32 \pm 868.47 \mathrm{mg} \mathrm{m}^{-2} \mathrm{~h}^{-1}\right)$ than their downstream counterparts $\left(621.14 \pm 704.10 \mathrm{mg} \mathrm{m}^{-2} \mathrm{~h}^{-1}\right)$. Mean $\mathrm{CO}_{2}$ emissions showed no significant differences in the grasslands, averaging $524.16 \pm 450.10 \mathrm{mg} \mathrm{m}^{-2} \mathrm{~h}^{-1}$ upstream and $508.06 \pm$ $534.77 \mathrm{mg} \mathrm{m}^{-2} \mathrm{~h}^{-1}$ downstream.

$\mathrm{CH}_{4}$ emissions showed a marked spatial pattern in the riparian zones from upstream to downstream (Fig. 6c).
The transects with continuous river flow were $\mathrm{CH}_{4}$ sources in the wet and dry seasons, with average emissions of $1.42 \pm 3.41$ and $0.27 \pm 0.49 \mathrm{mg} \mathrm{m}^{-2} \mathrm{~h}^{-1}$, respectively; while those with intermittent river flow served as $\mathrm{CH}_{4}$ sinks, with the corresponding means of $-0.21 \pm 0.45$ and $-0.02 \pm$ $0.05 \mathrm{mg} \mathrm{m}^{-2} \mathrm{~h}^{-1}$, respectively. Moreover, the hillslope grassland sites in all transects were $\mathrm{CH}_{4}$ sinks (Fig. 6d).

$\mathrm{N}_{2} \mathrm{O}$ emissions in riparian wetlands (Fig. 7e) showed spatial patterns similar to those of $\mathrm{CH}_{4}$ emissions. In the wet season, the transects with continuous river flow served as $\mathrm{N}_{2} \mathrm{O}$ sources, with a mean emission of $0.031 \pm$ $0.031 \mathrm{mg} \mathrm{m}^{-2} \mathrm{~h}^{-1}$; meanwhile, transects with intermittent 
Wet season
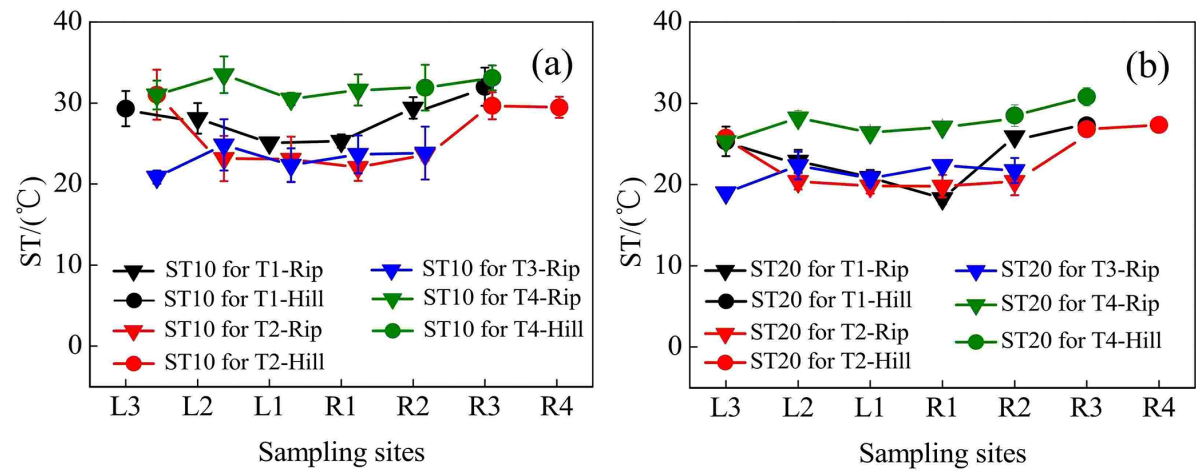

Dry season
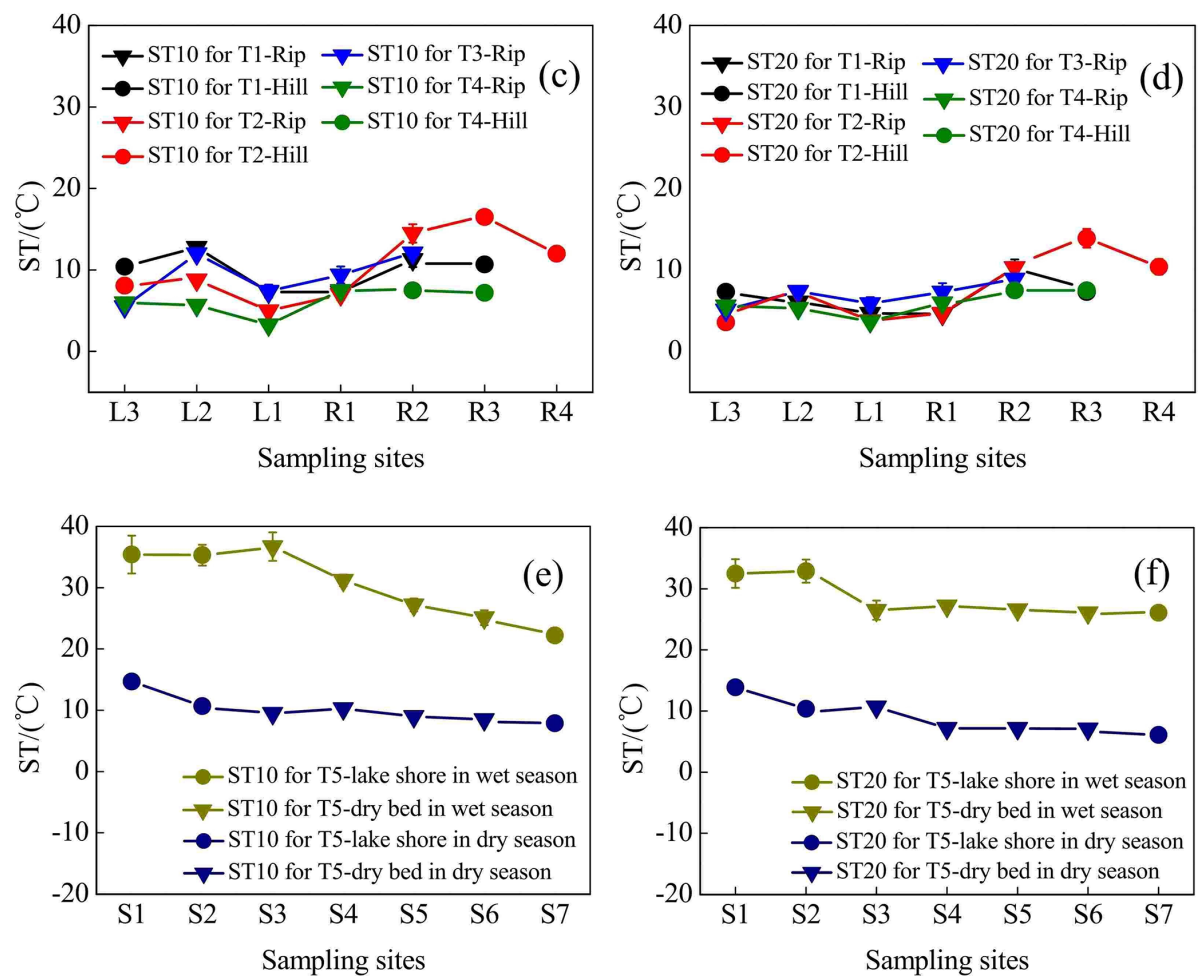

Figure 4. Soil temperatures (STs) at soil depths of 0-10 cm (ST10) and 10-20 cm (ST20) for transects T1-T5 in the wet and dry seasons. Error bars represent the SD about the mean.

Table 3. Significant correlations between GHGs fluxes and two seasons $(n=31)$.

\begin{tabular}{lrrr}
\hline GHG flux & $\begin{array}{r}F \mathrm{CO}_{2} \text { in the wet season }- \\
F \mathrm{CO}_{2} \text { in the dry season }\end{array}$ & $\begin{array}{r}F \mathrm{CH}_{4} \text { in the wet season }- \\
F \mathrm{CH}_{4} \text { in the dry season }\end{array}$ & $\begin{array}{r}F \mathrm{~N}_{2} \mathrm{O} \text { in the wet season - } \\
F \mathrm{~N}_{2} \mathrm{O} \text { in the dry season }\end{array}$ \\
\hline Significant correlations $(P)$ & 0.000 & 0.133 & 0.290 \\
\hline
\end{tabular}

Note: $P<0.05$ denotes significant correlation and $P>0.05$ denotes no significant correlation. 

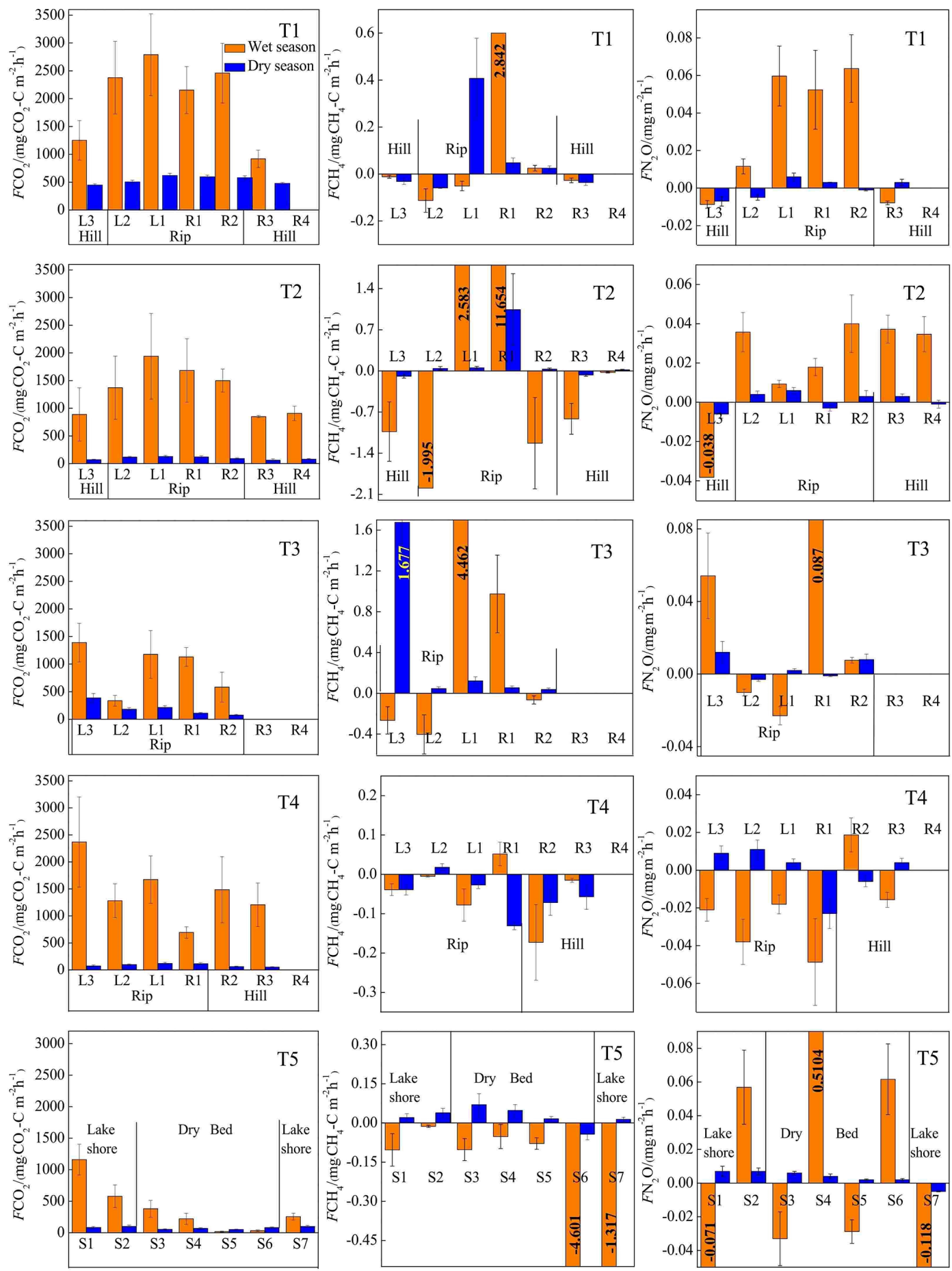

Figure 5. Spatiotemporal patterns of $\mathrm{CO}_{2}$ (first column), $\mathrm{CH}_{4}$ (second column), and $\mathrm{N}_{2} \mathrm{O}$ (third column) emission $(F)$ for each transect. Data are shown for the wet season (orange) and the dry season (blue). Error bars depict standard deviation. 

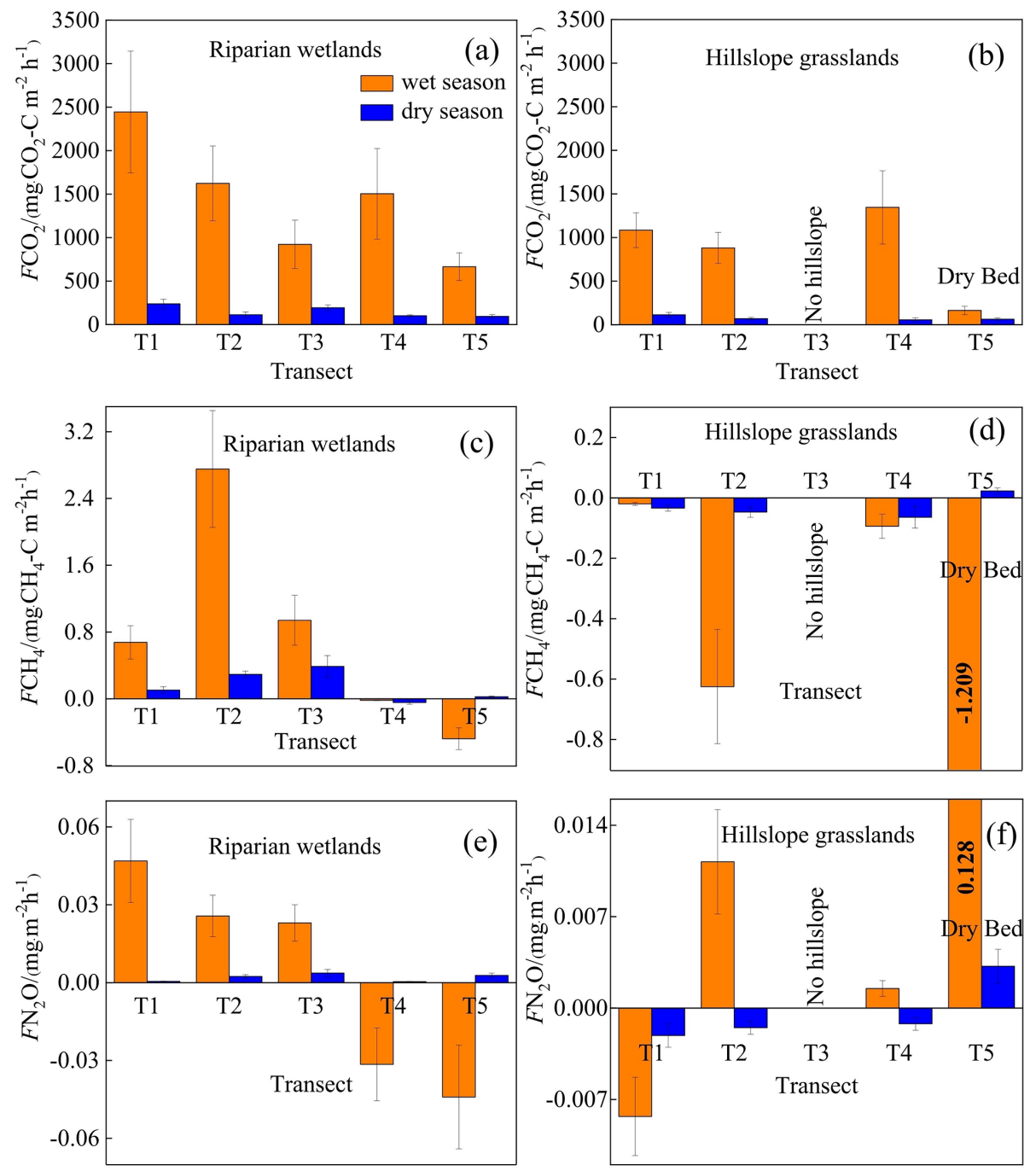

Figure 6. Spatiotemporal patterns of $\mathrm{CO}_{2}$ (first line), $\mathrm{CH}_{4}$ (second line), and $\mathrm{N}_{2} \mathrm{O}$ (third line) emissions $(F)$ in the upstream (T1, T2, and T3) and downstream areas (T4 and T5). Bars represent the mean values for each transect, and error bars show the standard errors.

river flow acted as $\mathrm{N}_{2} \mathrm{O}$ sinks with an average emission of $-0.037 \pm 0.05 \mathrm{mg} \mathrm{m}^{-2} \mathrm{~h}^{-1}$. In the dry season, $\mathrm{N}_{2} \mathrm{O}$ emissions occurred as weak sources in the longitudinal transects, exhibiting an average emission of $0.002 \pm 0.007 \mathrm{mg} \mathrm{m}^{-2} \mathrm{~h}^{-1}$. However, the $\mathrm{N}_{2} \mathrm{O}$ emission in the hillslope grasslands did not show any spatial patterns (Fig. 7f).

\section{Discussion}

\subsection{Main factors influencing GHG emissions}

\subsubsection{Effects of SMC on GHG emissions}

SMC constitutes one of the main factors affecting GHG emission in wetlands. In this study, transects $\mathrm{T} 1-\mathrm{T} 4$ were characterized by a marked spatial SMC gradient (i.e., a gradual decrease in SMC10 and SMC20 from the riparian wet- lands to the hillslope grasslands and from the upstream to downstream regions; Fig. 3). The $\mathrm{CO}_{2}, \mathrm{CH}_{4}$, and $\mathrm{N}_{2} \mathrm{O}$ emissions showed a similar trend. Table 4 shows that $\mathrm{SMC} 10$ is positively correlated with $\mathrm{CO}_{2}$ emission $(P<0.05)$ and that SMC10 and SMC20 are significantly positively correlated with $\mathrm{CH}_{4}$ emission $(P<0.01)$ and with $\mathrm{N}_{2} \mathrm{O}$ emission $(P<0.05$ and $P<0.01$, respectively). These results indicate the influence of wetland SMC on GHG emission.

Typically, the optimal SMC associated with $\mathrm{CO}_{2}$ emission in the riparian wetlands ranges from $40 \%$ to $60 \%$ (Sjögersten et al., 2006), creating better soil aeration, and improving soil microorganism activity and respiration in plant roots, thereby promoting $\mathrm{CO}_{2}$ emission. Excessive SMC reduces soil gas transfer due to the formation of an anaerobic environment in the soil, and microbial activity is lowered, favoring the accumulation of organic matter (Hui, 2014). The SMC of the hillslope grasslands was found to be less than $10 \%$. Low 

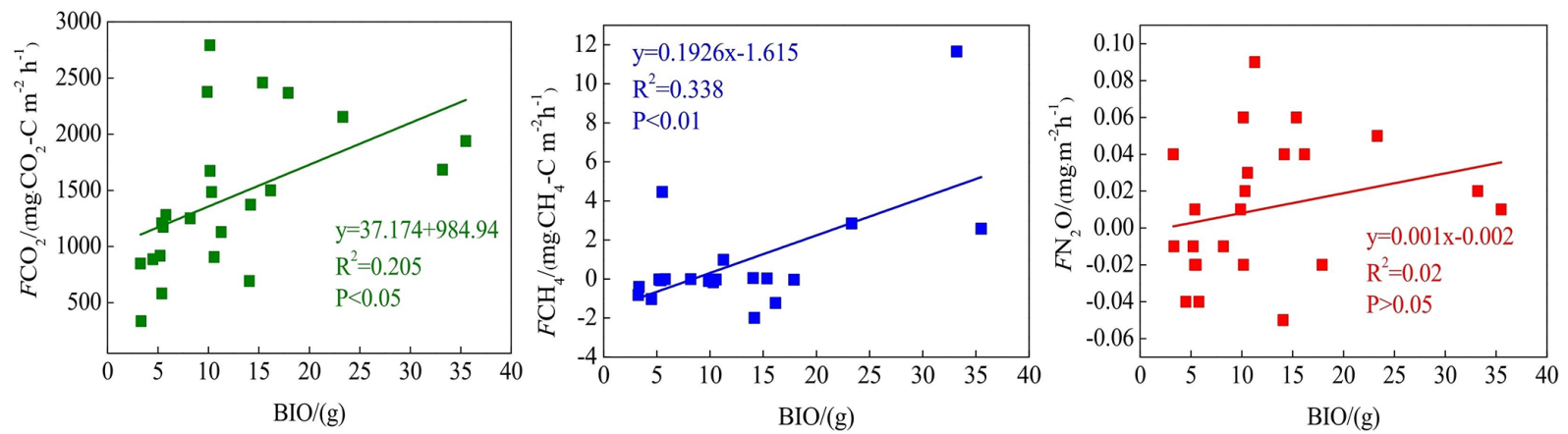

Figure 7. Correlation between aboveground biomass (BIO) and GHG emission $(F)$.

soil moisture inhibits the growth of vegetation, with few vegetation residues and litters. Meanwhile, low soil moisture is not conducive to the survival of soil microorganisms, leading to lower $\mathrm{CO}_{2}$ emission from the hillslope grasslands than from the riparian zones (Moldrup et al., 2000; Hui, 2014). Similar results were obtained in our study. The change in $\mathrm{CO}_{2}$ emission in transect T5 was contrary to the changes in SMC10 and SMC20, likely because the optimal range of soil C : N is between 10-12 (Pierzynski et al., 1994), but the value in the dry lake bed of $\mathrm{T} 5$ is higher than 60 . The high soil $\mathrm{C}: \mathrm{N}$ resulted in nitrogen limitation in the process of decomposition of organic matter by microorganisms. Further, other sediment properties (like Soil $\mathrm{pH}>9.5$ ) for this transect were not conducive to the survival of microorganisms (Table 1), and the increase in SMC did not increase the respiration activity of the microorganisms.

The highest $\mathrm{CH}_{4}$ emissions were observed at the nearstream sites (i.e., L1 and R1) in T1, T2, and T3, with average SMC of $30.29 \%$, while the SMC at the other sites, which were either weak sources or sinks, averaged at $14.57 \%$. These results indicate that a higher SMC is favorable for $\mathrm{CH}_{4}$ emissions. This may be because a higher SMC accompanies soil in a reduced state, which is beneficial for $\mathrm{CH}_{4}$ production and inhibits $\mathrm{CH}_{4}$ oxidation. A similar result was reported by Xu et al. (2008). They conducted experiments analyzing $\mathrm{CH}_{4}$ emissions from a variety of paddy soils in China and showed that $\mathrm{CH}_{4}$ production rates increased with the increase in SMC at the same incubation temperature. Meng et al. (2011) also reported that water depth was the main factor affecting $\mathrm{CH}_{4}$ emissions from wetlands. When the water level dropped below the soil surface, the decomposition of organic matter accelerated, and $\mathrm{CH}_{4}$ emission decreased. If the oxide layer is large, the soil is transformed into a $\mathrm{CH}_{4}$ sink (Meng et al., 2011).

The $\mathrm{N}_{2} \mathrm{O}$ fluxes showed a clear spatial pattern associated with the changes in SMC. The moisture content of wetland soils directly affects the aeration status of the soil. Besides, the aeration status affects the partial pressure of oxygen, which has an important impact on nitrifying and denitrifying bacterial activity and ultimately affects soil $\mathrm{N}_{2} \mathrm{O}$ emissions
(Zhang et al., 2005). Table 4 shows that $\mathrm{N}_{2} \mathrm{O}$ emission is significantly positively correlated with SMC10 and SMC20 $(P<0.01)$. Generally, when SMC is below the saturated water content, the microorganisms are in an aerobic environment, and $\mathrm{N}_{2} \mathrm{O}$ mainly comes from the nitrification reaction. $\mathrm{N}_{2} \mathrm{O}$ emission increases with increase in SMC (Niu et al., 2017; Yu et al., 2006). In our study, the sampling sites with higher SMC (riparian zones and some hillslope grassland zones in the upstream transects) have higher $\mathrm{N}_{2} \mathrm{O}$ emissions. When SMC increases to the saturated water content or is in a flooded state, the system is an anaerobic environment, and the nitrous oxide reductase activity is higher due to excessively high $\mathrm{SMC}$, which is conducive to denitrification and eventually produces $\mathrm{N}_{2}$ (Niu et al., 2017; Yu et al., 2006), such as at site L1 in transect T3 in this study. Rückauf et al. (2004) showed that denitrification was the main process under flooded soil conditions in wetland soils and that the release of $\mathrm{N}_{2}$ exceeds that of $\mathrm{N}_{2} \mathrm{O}$. These findings are consistent with those of Liu et al. (2003), who showed that $\mathrm{SMC}$ is an essential factor affecting $\mathrm{N}_{2} \mathrm{O}$ emission.

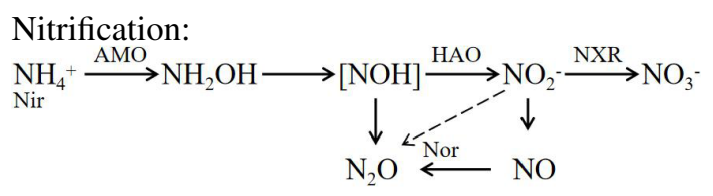

Denitrification:

$\mathrm{NO}_{3} \cdot \stackrel{\mathrm{Nar}}{\longrightarrow} \mathrm{NO}_{2} \cdot \stackrel{\mathrm{Nir}}{\longrightarrow} \mathrm{NO} \stackrel{\mathrm{Nor}}{\longrightarrow} \mathrm{N}_{2} \mathrm{O} \stackrel{\mathrm{Nos}}{\longrightarrow} \mathrm{N}_{2}$

The enzymes involved in the formula include ammonia monooxygenase (AMO), hydroxylamine oxidase (HAO), nitrite REDOX enzyme (HAO), nitrate reductase (Nar), nitrite reductase (Nir), nitric oxide reductase (Nor), and nitrous oxide reductase (Nos).

\subsubsection{Effects of ST on GHG emissions}

ST was another important factor affecting $\mathrm{CO}_{2}$ emission in this study; it was found to be significantly correlated with $\mathrm{CO}_{2}$ emission $(P<0.01)$ (Table 4$)$. The activity of soil microorganisms increases with rising soil temperature, leading 
to increased respiration and consequently higher $\mathrm{CO}_{2}$ emission (Heilman et al., 1999). Previous studies have reported that ST partially controls seasonal $\mathrm{CO}_{2}$ emission patterns (Inubushi et al., 2003). Concurrently, $\mathrm{CO}_{2}$ emissions in the wet season were significantly higher than those in the dry season in this study.

$\mathrm{CH}_{4}$ emissions showed a clear seasonal pattern, likely because high summer temperatures improve the activity of both $\mathrm{CH}_{4}$-producing and $\mathrm{CH}_{4}$-oxidizing bacteria (Ding et al., 2010). However, as Table 4 indicates, the correlation between $\mathrm{CH}_{4}$ emission and temperature was not significant in this study, likely because SMC was a more critical factor than temperature in our study region given its very dry climate. SMC showed a positive correlation with GHG emissions. In addition, SMC affected ST to a certain extent, while the interactions between SMC and ST had a mutual influence on $\mathrm{CH}_{4}$ emission. During the study period, the near-stream sites (L1 and R1) maintained a super-wet state on the ground surface for a long time, which was beneficial for the production of $\mathrm{CH}_{4}$. However, the wetlands maintained a state without water accumulation on the soil surface in August, which was conducive to the oxidative absorption of $\mathrm{CH}_{4}$. SMC thus masked the effect of ST on $\mathrm{CH}_{4}$ emissions.

Previous studies have indicated that temperature is an important factor affecting $\mathrm{N}_{2} \mathrm{O}$ emission (Sun et al., 2011) through primary mechanisms impacting the nitrifying and denitrifying bacteria in the soil. As Table 4 shows, the correlations between $\mathrm{N}_{2} \mathrm{O}$ emission and ST10 and ST20 were poor $(P>0.05)$. This can be attributed to the wide suitable temperature range for nitrification-denitrification and weak sensitivity to temperature. Malhi and Mcgill (1982) found that the optimum temperature for nitrification was $20^{\circ} \mathrm{C}$ and that it inhibits entirely at $30^{\circ} \mathrm{C}$. However, Brady (1999) believed that the suitable temperature range for nitrification is $25-35^{\circ} \mathrm{C}$ and that nitrification inhibits below $5^{\circ} \mathrm{C}$ or above $50^{\circ} \mathrm{C}$. This shows that the temperature requirements of nitrifying microorganisms in wetland soils are possibly different in different temperature belts. The suitable temperature range was the performance of the long-term adaptability of nitrifying microorganisms. Meanwhile, several studies have revealed that denitrification can be carried out in a wide temperature range $\left(5-70^{\circ} \mathrm{C}\right)$ and that it is positively related to temperature (Fan, 1995). However, the process is inhibited when the temperature is too high or too low. The average ST in the wet season was $27.4^{\circ} \mathrm{C}$, conducive to the growth of denitrifying microorganisms, while that in the dry season was $8.97^{\circ} \mathrm{C}$, and the microbial activity was generally low (Sun et al., 2011). Furthermore, ST fluctuations were low in both the wet and dry seasons. Therefore, the effect of ST on $\mathrm{N}_{2} \mathrm{O}$ emission may have been masked by other factors, such as moisture content.

\subsubsection{Effects of BIO and soil organic matter content on GHG emissions}

$\mathrm{CO}_{2}$ and $\mathrm{CH}_{4}$ emissions were higher in the riparian wetlands than in the grasslands, mainly because of the greater vegetation cover in the former. Typically, $\mathrm{CO}_{2}$ emissions in the riparian wetlands originate from plants and microorganisms, with plant respiration accounting for a large proportion in the growing season. Previous studies have shown that plant respiration accounts for $35 \%-90 \%$ of the total respiration in the wetland ecosystem (Johnson-Randall and Foote, 2005). The good soil physicochemical properties and high soil TOC content of the riparian wetlands improve both the activity of soil microorganisms and plant root respiration. As Table 4 shows, BIO is significantly correlated with $\mathrm{CO}_{2}(P<0.05)$ and $\mathrm{CH}_{4}(P<0.01)$ emissions. These results are indicated by the significant linear positive correlation between the respiration rate and plant biomass (Lu et al., 2007). Higher plant biomass storage can achieve more carbon accumulation during photosynthesis and higher exudate release by the roots. This, in turn, promotes the accumulation of soil organic matter. An increased amount of organic matter stimulates the growth and reproduction of soil microorganisms, ultimately promoting $\mathrm{CO}_{2}$ and $\mathrm{CH}_{4}$ emission. Moreover, plants act as gas channels for $\mathrm{CH}_{4}$ transmission, and a larger amount of biomass promotes $\mathrm{CH}_{4}$ emission, given the increased number of channels. In transect $\mathrm{T} 3$, the high $\mathrm{CO}_{2}$ emission observed at site L3 can be attributed to the relatively high levels of SMC, BIO, and soil nutrients, which stimulate microbial respiration rates.

BIO had a weak correlation with $\mathrm{N}_{2} \mathrm{O}$ emission (Table 4), which indicates that plants increase $\mathrm{N}_{2} \mathrm{O}$ production and emission, although this may not be the most critical factor. Previous studies have reported mechanisms wherein the plants are able to absorb the $\mathrm{N}_{2} \mathrm{O}$ produced in the soil through the root system before releasing it into the atmosphere. Additionally, the root exudates of plants can enhance the activity of nitrifying and denitrifying bacteria in the soil, ultimately promoting the production of $\mathrm{N}_{2} \mathrm{O}$. Finally, oxygen stress caused by plant respiration can regulate the production and consumption of $\mathrm{N}_{2} \mathrm{O}$ in the soil, eventually affecting the conversion of nitrogen in the soil (Koops et al., 1996; Azam et al., 2005).

Site L3 in transect T3 was covered by tall reeds, and its BIO was much higher than that of any of the other sites; thus, the data for this site were excluded from the correlation analysis.

Soil $\mathrm{C}: \mathrm{N}$ ratio refers to the ratio of the concentration of biodegradable carbonaceous organic matter to nitrogenous matter in the soil, and it forms a soil matrix with TOC. TOC decomposition provides energy for microbial activity, while the $\mathrm{C}: \mathrm{N}$ ratio affects the decomposition of organic matter by soil microorganisms (Gholz et al., 2000). The correlation results (Fig. 8) indicate that TOC had a weak positive correlation with $\mathrm{CO}_{2}$ emission $(P>0.05)$, but the soil $\mathrm{C}: \mathrm{N}$ 
ratio had a significant negative correlation with $\mathrm{CO}_{2}$ emission $(P<0.05)$, indicating that nitrogen has a limiting effect on soil respiration by affecting microbial metabolism. Liu (2019) have reported that $\mathrm{N}$ addition promotes $\mathrm{CO}_{2}$ emission from wetlands soil, and the effect of organic $\mathrm{N}$ input was significantly higher than that of inorganic $\mathrm{N}$ input. Organic carbon acts as a carbon source for the growth of plants and microorganisms, which boosts their respiration. Moreover, TOC has a significant correlation with $\mathrm{N}_{2} \mathrm{O}$ emissions $(P<0.05)$. Most heterotrophic microorganisms use soil organic matter as carbon and electron donors (Morley and Baggs, 2010). Soil carbon sources have an important influence on microbial activity. Nitrifying or denitrifying microorganisms need organic matter to act as the carbon source during the assimilation of $\mathrm{NH}_{3}$ or $\mathrm{NO}_{3}{ }^{-}$. High content of organic matter in the soil can promote the concentration of heterotrophic nitrifying bacteria, consume dissolved oxygen in the medium, and cause the soil to become more anaerobic, thereby slowing down autotrophic growth nitrifying bacteria. This reduces the nitrification rate, ultimately promoting $\mathrm{N}_{2} \mathrm{O}$ release. Enwall et al. (2005) studied the effect of long-term fertilization on soil denitrification microbial action intensity. They found that the soil with long-term organic fertilizer application has a significant increase in organic matter content and consequently a significant increase in denitrification activity. Typically, low soil $\mathrm{C}: \mathrm{N}$ ratios are favorable for the decomposition of microorganisms, the most suitable range being between 10 and 12 (Pierzynski et al., 2005). As Table 4 shows, $\mathrm{N}_{2} \mathrm{O}$ emission was significantly related to the soil $\mathrm{C}: \mathrm{N}$ ratios $(P<0.05)$, which means that denitrifying bacteria could use their endogenous carbon source for denitrification when the external carbon source was insufficient. Moreover, incomplete denitrification leads to the accumulation of $\mathrm{NO}_{2}-\mathrm{N}$, which is conducive to $\mathrm{N}_{2} \mathrm{O}$ release. Meanwhile, due to the weak competitive ability of Nos to electrons, a low soil $\mathrm{C}: \mathrm{N}$ ratio inhibits the synthesis of Nos, which is also a reason for $\mathrm{N}_{2} \mathrm{O}$ release. In this study, all sites in transects $\mathrm{T} 1-\mathrm{T} 4$ exhibited similar soil $\mathrm{C}: \mathrm{N}$ ratios in the optimum range (Table 1), which is favorable for microbial decomposition. However, the soil $\mathrm{C}: \mathrm{N}$ ratios in transect $\mathrm{T} 5$ were higher than those in the other transects, especially in the dry lake bed. Therefore, transect T5 showed severe mineralization and a low microbial decomposition rate.

\subsection{Riparian wetlands as hotspots of GHG emissions}

The results of this study emphasized that the rate of $\mathrm{CO}_{2}$ emission in the riparian wetlands was higher than that in the hillslope grasslands, owing to a variety of factors. ST is an important factor affecting GHG emission. Mclain and Martens (2006) showed that seasonal fluctuations in ST and SMC in semi-arid regions have important effects on $\mathrm{CO}_{2}$, $\mathrm{CH}_{4}$, and $\mathrm{N}_{2} \mathrm{O}$ emissions in riparian soils. Poblador et al. (2017) studied the GHG emission in forest riparian zones and suggested that the difference in the $\mathrm{CO}_{2}$ and $\mathrm{N}_{2} \mathrm{O}$ emis- sions in these zones is caused by the spatial gradient of the regional SMC. In this study, the upstream riparian wetlands were characterized by higher TOC content, lower soil $\mathrm{C}: \mathrm{N}$ ratio, and more abundant $\mathrm{BIO}$ than those in the hillslope grasslands (Table 1). These soil conditions benefited the soil microbial activity, ultimately enhancing respiration as well as $\mathrm{CO}_{2}$ emissions. However, the $\mathrm{CO}_{2}$ emission in the downstream areas was nearly identical to that in the grasslands, likely because the wetlands gradually evolved into grasslands after their degradation. $\mathrm{N}_{2} \mathrm{O}$ emission showed spatial patterns similar to that of $\mathrm{CO}_{2}$ emission, likely because the $\mathrm{CO}_{2}$ concentration was closely related to the nitrification and denitrification processes. High $\mathrm{CO}_{2}$ concentrations can promote the carbon and nitrogen cycles in soil (Azam et al., 2005), increasing belowground $C$ allocation, which is associated with increased root biomass, root turnover, and root exudation. Elevated $p \mathrm{CO}_{2}$ in plants provides the energy for denitrification in the presence of high available $\mathrm{N}$, and there is increased $\mathrm{O}_{2}$ consumption under elevated $p \mathrm{CO}_{2}$ (Baggs et al., 2003). Moreover, soil respiration increases during soil denitrification (Liu et al., 2010; Christensen et al., 1990). In this study, a weak correlation was observed between the $\mathrm{CO}_{2}$ and $\mathrm{CH}_{4}$ emissions in the riparian zones $(r=0.228)$, but $\mathrm{CO}_{2}$ emission was significantly correlated with $\mathrm{N}_{2} \mathrm{O}$ emis$\operatorname{sion}(r=0.322, P<0.05)$. The soil became anaerobic in the riparian areas as the SMC increased, and this was conducive to the survival of $\mathrm{CH}_{4}$-producing bacteria and to denitrification reactions, eventually leading to an increase in $\mathrm{CH}_{4}$ and $\mathrm{N}_{2} \mathrm{O}$ emissions. Jacinthe et al. (2015) reported that inundated grassland-dominated riparian wetlands were $\mathrm{CH}_{4}$ sinks $\left(-1.08 \pm 0.22 \mathrm{~kg} \mathrm{CH}_{4}-\mathrm{Cha}^{-1} \mathrm{yr}^{-1}\right)$, and Lu et al. (2015) also indicated that grasslands were $\mathrm{CH}_{4}$ sinks. In our study, a marked water gradient across the transects led to the transformation of the soil from anaerobic to aerobic soil, which changed the wetland to either a $\mathrm{CH}_{4}$ source or sink. Therefore, during the transition from the riparian wetlands to the hillslope grasslands, $\mathrm{CH}_{4}$ sources only appeared in the nearstream sites, while sinks appeared at other sites.

Further, we compared the GHG emissions in the riparian wetlands and the hillslope grasslands around the Xilin River basin with those in various types of grasslands (meadow grassland, typical grassland, and desert grassland) in the Xilingol League in Inner Mongolia (Table 5). $\mathrm{CO}_{2}$ emission in the wet season decreased in the following order: upstream riparian wetlands $>$ downstream riparian wetlands $>$ hillslope grasslands $>$ meadow grassland $>$ typical grassland $>$ desert grassland. Moreover, the upper riparian wetlands acted as sources of $\mathrm{CH}_{4}$ emission, while the downstream transects and grasslands served as $\mathrm{CH}_{4}$ sinks. Similarly, except in the downstream transects, $\mathrm{N}_{2} \mathrm{O}$ emissions occurred as weak sources in different types of grasslands and upstream riparian wetlands. The GHG emissions showed similar spatial patterns in October. Although these estimates were made only in the growing season in August and the non-growing season in October, our results suggest that the riparian wet- 

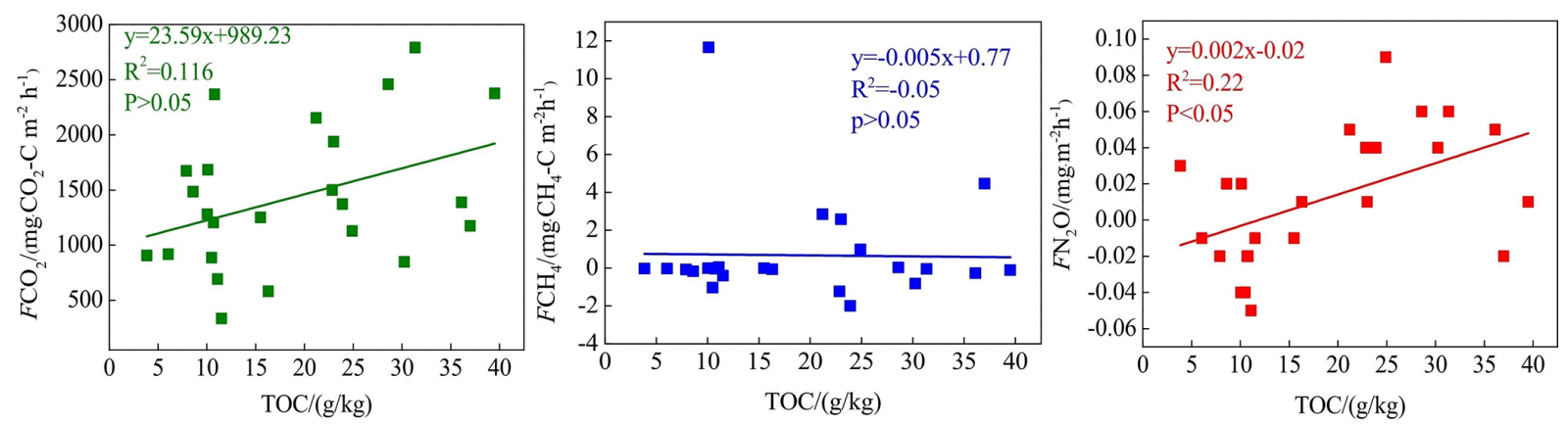

Figure 8. Correlations between soil organic carbon (TOC) content and GHG emission $(F)$.

Table 4. Correlations between $\mathrm{CO}_{2}, \mathrm{CH}_{4}$, and $\mathrm{N}_{2} \mathrm{O}$ emissions and impact factors $(n=62)$.

\begin{tabular}{lrrrrrrrrrr}
\hline GHG flux & ST10 & ST20 & SMC10 & SMC20 & TOC & $\rho_{\mathrm{b}}$ & C : N & pH & EC & BIO \\
\hline $\mathrm{CO}_{2}$ & $0.634^{\mathrm{b}}$ & $0.592^{\mathrm{b}}$ & $0.307^{\mathrm{a}}$ & 0.216 & 0.393 & $-0.463^{\mathrm{b}}$ & $-0.289^{\mathrm{b}}$ & $-0.350^{\mathrm{b}}$ & $-0.251^{\mathrm{a}}$ & $0.491^{\mathrm{a}}$ \\
$\mathrm{CH}_{4}$ & -0.029 & -0.051 & $0.346^{\mathrm{b}}$ & $0.353^{\mathrm{b}}$ & -0.02 & -0.129 & -0.156 & -0.127 & -0.107 & $0.607^{\mathrm{b}}$ \\
$\mathrm{N}_{2} \mathrm{O}$ & 0.127 & 0.118 & $0.304^{\mathrm{a}}$ & $0.356^{\mathrm{b}}$ & $0.493^{\mathrm{a}}$ & -0.194 & $0.311^{\mathrm{a}}$ & 0.137 & $0.504^{\mathrm{b}}$ & 0.251 \\
\hline
\end{tabular}

Note: 1 . The analysis method used in the table is Pearson correlation analysis, and the numbers represent Pearson correlation coefficients. $2 .{ }^{\mathrm{a}}$ and ${ }^{\mathrm{b}}$ denote significant and highly significant correlations $(P<0.05$ and $P<0.01)$, respectively. 3. ST - soil temperature, SMC - soil moisture content, $\rho_{\mathrm{b}}-$ soil bulk density, soil $\mathrm{C}: \mathrm{N}$ - soil carbon-nitrogen ratio, $\mathrm{pH}$ - soil $\mathrm{pH}, \mathrm{EC}$ - soil electrical conductivity, and $\mathrm{BIO}$ - aboveground biomass.

lands are the potential hotspots of GHG emission. Thus, it is important to study GHG emission to obtain a comprehensive picture of the role of the riparian wetlands in climate change.

We roughly estimated the annual cumulative emission amounts of $\mathrm{CO}_{2}, \mathrm{CH}_{4}$, and $\mathrm{N}_{2} \mathrm{O}$ from the riparian wetlands and hillslope grasslands around the Xilin River basin and further calculated their global warming potential. As Table 6 indicates, annual cumulative emissions of $\mathrm{CO}_{2}$ and $\mathrm{CH}_{4}$ decreased in the following order: upstream riparian wetlands $>$ downstream riparian wetlands $>$ hillslope grasslands. $\mathrm{N}_{2} \mathrm{O}$ decreased in the following order: upstream riparian wetlands $>$ hillslope grasslands $>$ downstream riparian wetlands. In this study, we used the static dark-box method to measure $\mathrm{CO}_{2}$ emissions, which does not consider the absorption and fixation of $\mathrm{CO}_{2}$ by plant photosynthesis. Therefore, the total annual cumulative $\mathrm{CO}_{2}$ emissions are high. This result clearly showed the more significant impact of $\mathrm{CO}_{2}$ emission than that of $\mathrm{CH}_{4}$ and $\mathrm{N}_{2} \mathrm{O}$ emissions on global warming. The GWP depends on the cumulative emissions of the GHGs. The GWPs, shown in Table 6, were in the following order: upstream riparian wetlands $\left(13474.91 \mathrm{~kg} \mathrm{hm}^{-2}\right)$ $>$ downstream riparian wetlands $\left(8974.12 \mathrm{~kg} \mathrm{hm}^{-2}\right)>$ hillslope grasslands $\left(8351.24 \mathrm{~kg} \mathrm{hm}^{-2}\right)$. Therefore, both the riparian wetlands and the grasslands are the "sources" of GHGs on a 100-year timescale. The source strength of the wetlands is higher than that of the grasslands, further indicating that the riparian wetlands are hotspots of GHG emission.

\subsection{Effects of riparian wetland degradation on GHG emissions}

The hydrology and soil properties showed evident differences between transects because the downstream zone was dry all year due to the presence of the Xilinhot Dam (Fig. 1). The dam caused the degradation of the riparian wetlands, resulting in reduced GHG emission. The average $\mathrm{CO}_{2}$ emission amounted to $1663 \mathrm{mg} \mathrm{m}^{-2} \mathrm{~h}^{-1}$ in the upstream transects (T1, T2, and T3) at the riparian wetlands, while the downstream transects (T4 and T5) recorded an average emission of $1084 \mathrm{mg} \mathrm{m}^{-2} \mathrm{~h}^{-1}, 35 \%$ lower than that in the upstream transects. The $\mathrm{N}_{2} \mathrm{O}$ emission from the riparian wetlands was lower in the downstream transects.

Wetland degradation first resulted in the continuous reduction of SMC, which led to the deepening of the wetland's aerobic layer thickness. Besides, SMC may affect ST and thus transport the $\mathrm{CH}_{4}$ emissions from a source to a sink by affecting methanogen activity (Yan et al., 2018). Second, the reduction of SMC impeded physiological activities of aboveground plants and inhabited related enzyme activities in the respiration process. Meanwhile, various enzyme reactions of underground microorganisms under water stress influence and reduced $\mathrm{CO}_{2}$ emissions (Zhang et al., 2017). Finally, after wetland degradation, long-term drought led to an extremely low SMC, which is not conducive to the growth of nitrifying and denitrifying bacteria and causes the transport of $\mathrm{N}_{2} \mathrm{O}$ emissions from source to sink (Zhu et al., 2013). As Table 1 shows, soil TOC content in the upstream transects (average: $25.1 \mathrm{~g} \mathrm{~kg}^{-1}$ ) was higher than that in the down- 
Table 5. GHG emission fluxes of riparian wetlands and grasslands.

\begin{tabular}{|c|c|c|c|c|c|c|c|c|}
\hline \multirow[t]{2}{*}{ Sample plot } & & \multicolumn{3}{|c|}{$\begin{array}{l}\text { GHG emissions in August } \\
\left(\mathrm{mg} \mathrm{m}^{-2} \mathrm{~h}^{-1}\right)\end{array}$} & \multicolumn{3}{|c|}{$\begin{array}{l}\text { GHG emissions in October } \\
\left(\mathrm{mg} \mathrm{m}^{-2} \mathrm{~h}^{-1}\right)\end{array}$} & \multirow[t]{2}{*}{ Reference } \\
\hline & & $\mathrm{CO}_{2}$ & $\mathrm{CH}_{4}$ & $\mathrm{~N}_{2} \mathrm{O}$ & $\mathrm{CO}_{2}$ & $\mathrm{CH}_{4}$ & $\mathrm{~N}_{2} \mathrm{O}$ & \\
\hline $\begin{array}{l}\text { Wetlands of upstream } \\
\text { transects } \\
(\mathrm{T} 1, \mathrm{~T} 2 \text {, and } \mathrm{T} 3)\end{array}$ & $n=13$ & $\begin{array}{l}1606.28 \pm \\
697.78\end{array}$ & $\begin{array}{l}1.417 \pm \\
3.41\end{array}$ & $\begin{array}{l}0.031 \pm \\
0.03\end{array}$ & $\begin{array}{l}182.35 \pm \\
88.26\end{array}$ & $\begin{array}{l}0.272 \pm \\
0.49\end{array}$ & $\begin{array}{l}0.002 \pm \\
0.005\end{array}$ & $\begin{array}{l}\text { This } \\
\text { study }\end{array}$ \\
\hline $\begin{array}{l}\text { Wetlands of down- } \\
\text { stream transects } \\
\text { (T4 and T5) }\end{array}$ & $n=7$ & $\begin{array}{l}1144.15 \pm \\
666.50\end{array}$ & $\begin{array}{l}-0.215 \pm \\
0.45\end{array}$ & $\begin{array}{l}-0.037 \pm \\
0.05\end{array}$ & $\begin{array}{l}98.13 \pm \\
15.11\end{array}$ & $\begin{array}{l}-0.015 \pm \\
0.05\end{array}$ & $\begin{array}{l}0.001 \pm \\
0.01\end{array}$ & \\
\hline $\begin{array}{l}\text { Hillslope grasslands of } \\
\text { all transects }\end{array}$ & $n=7$ & $\begin{array}{l}1071.54 \pm \\
225.39\end{array}$ & $\begin{array}{l}-0.300 \pm \\
0.40\end{array}$ & $\begin{array}{l}0.003 \pm \\
0.03\end{array}$ & $\begin{array}{l}77.68 \pm \\
25.32\end{array}$ & $\begin{array}{l}-0.048 \pm \\
0.03\end{array}$ & $\begin{array}{l}-0.002 \pm \\
0.005\end{array}$ & \\
\hline Meadow grassland & & $\begin{array}{l}166.39 \pm \\
45.89\end{array}$ & $\begin{array}{l}-0.038 \pm \\
0.009\end{array}$ & $\begin{array}{l}0.002 \pm \\
0.001\end{array}$ & - & - & - & $\begin{array}{l}\text { Guo et al. } \\
(2017)\end{array}$ \\
\hline Typical grassland & & $\begin{array}{l}240.32 \pm \\
87.56\end{array}$ & $\begin{array}{l}-0.042 \pm \\
0.025\end{array}$ & $\begin{array}{l}0.037 \pm \\
0.034\end{array}$ & - & - & - & \\
\hline Desert grassland & & $\begin{array}{l}107.59 \pm \\
54.10\end{array}$ & $\begin{array}{l}-0.036 \pm \\
0.015\end{array}$ & $\begin{array}{l}0.003 \pm \\
0.001\end{array}$ & - & - & - & \\
\hline Typical grassland & & $\begin{array}{l}520.25 \pm \\
59.07\end{array}$ & $\begin{array}{l}-0.102 \pm \\
0.012\end{array}$ & $\begin{array}{l}0.007 \pm \\
0.001\end{array}$ & $\begin{array}{l}88.34 \pm \\
9.84\end{array}$ & $\begin{array}{l}-0.099 \pm \\
0.003\end{array}$ & $\begin{array}{l}0.005 \pm \\
0.001\end{array}$ & $\begin{array}{l}\text { Zhang } \\
(2019)\end{array}$ \\
\hline Typical grassland & & $\begin{array}{l}232.42 \pm \\
18.90\end{array}$ & $\begin{array}{l}-0.090 \pm \\
0.005\end{array}$ & $\begin{array}{l}0.004 \pm \\
0.001\end{array}$ & - & - & - & $\begin{array}{l}\text { Chao } \\
(2019)\end{array}$ \\
\hline Typical grassland & & $\begin{array}{l}265.23 \pm \\
31.43\end{array}$ & $\begin{array}{l}-0.185 \pm \\
0.018\end{array}$ & $\begin{array}{l}0.005 \pm \\
0.001\end{array}$ & $\begin{array}{l}189.41 \pm \\
28.96\end{array}$ & $\begin{array}{l}-0.092 \pm \\
0.012\end{array}$ & $\begin{array}{l}0.004 \pm \\
0.001\end{array}$ & \\
\hline Meadow grassland & & 553.85 & -0.163 & 0.003 & 47.73 & -0.019 & 0.011 & $\begin{array}{l}\text { Geng } \\
(2004)\end{array}$ \\
\hline Typical grassland & & 308.60 & -0.105 & 0.002 & 70.25 & -0.029 & 0.007 & \\
\hline
\end{tabular}

Table 6. Cumulative annual emission flux and global warming potential of GHGs in riparian wetlands and grasslands.

\begin{tabular}{lrrrr}
\hline Sample plot & $\mathrm{CO}_{2} / \mathrm{kg} \mathrm{hm}^{-2}$ & $\mathrm{CH}_{4} / \mathrm{kg} \mathrm{hm}^{-2}$ & $\mathrm{~N}_{2} \mathrm{O} / \mathrm{kg} \mathrm{hm}^{-2}$ & $\mathrm{GWP}^{-\mathrm{CO}_{2} \mathrm{~kg} \mathrm{hm}}{ }^{2}$ \\
\hline Wetlands of upstream transects (T1, T2, and T3) & $13092.80 \pm 5378.16$ & $12.36 \pm 26.40$ & $0.25 \pm 0.23$ & $13474.91 \pm 5828.68$ \\
Wetlands of downstream transects (T4 and T5) & $9093.47 \pm 4831.82$ & $-1.68 \pm 3.23$ & $-0.26 \pm 0.40$ & $8974.12 \pm 4912.75$ \\
Hillslope grasslands of all transects & $8412.26 \pm 1614.26$ & $-2.55 \pm 3.12$ & $0.01 \pm 0.20$ & $8351.24 \pm 1648.22$ \\
\hline
\end{tabular}

stream transects (average: $8.41 \mathrm{~g} \mathrm{~kg}^{-1}$ ). The relatively low SMC and the aerobic environment were conducive to the mineralization and decomposition of the TOC. The degradation of plants in the wetlands led to the gradual reduction of BIO. Ultimately, the plant carbon source input of the degraded wetlands decreased, and the bare land temperature increased due to the reduced plant shelter. This accelerated the decomposition of TOC, leading to its decrease. This result indicates that wetland degradation caused the soil carbon pool's loss and weakened the wetland carbon source-sink function. These results are in agreement with those of Xia et al. (2017).
The degraded wetlands also caused soil desertification and salinization, leading to a decline in the physical protection afforded by organic carbon and a reduction in soil aggregates. Thus, the preservative effect provided by organic carbon declined. The TOC content and SMC in the dry lake bed in transect T5 were relatively high; however, the GHG emission was very low along this transect because soil $\mathrm{pH}$ values increased after the degradation of the lake soil, exceeding the optimum range required for microorganism activity. The soil $\mathrm{C}: \mathrm{N}$ ratio was very high, resulting in severe mineralization and a low microbial decomposition rate, thus affecting the GHG emissions. 


\section{Conclusions}

The riparian wetlands in the Xilin River basin constitute a dynamic ecosystem. The present spatial and temporal transfers in the studied biogeochemical processes were attributed to the changes in SMC, ST, and soil substrate availability. Our simultaneous analysis of $\mathrm{CO}_{2}, \mathrm{CH}_{4}$, and $\mathrm{N}_{2} \mathrm{O}$ emissions from the riparian wetlands and the hillslope grasslands in the Xilin River basin revealed that the majority of the GHG emissions occurred in the form of $\mathrm{CO}_{2}$. Moreover, our results clearly illustrate a marked seasonality and spatial pattern of GHG emissions along the transects and in the longitudinal direction (i.e., upstream and downstream). SMC and ST were two critical factors controlling the GHG emissions. Moreover, the abundant $\mathrm{BIO}$ promoted the $\mathrm{CO}_{2}, \mathrm{CH}_{4}$, and $\mathrm{N}_{2} \mathrm{O}$ emissions.

The riparian wetlands are potential hotspots of GHG emissions in the Inner Mongolian region. However, the degradation of these wetlands has transformed the area from a source to a sink for $\mathrm{CH}_{4}$ and $\mathrm{N}_{2} \mathrm{O}$ emissions and reduced $\mathrm{CO}_{2}$ emissions, which has severely affected the wetland carbon cycle processes. Our results show that though the riparian wetlands have high $\mathrm{CO}_{2}$ emissions, the wetlands are $\mathrm{CO}_{2}$ sinks due to the photosynthesis of plants. Overall, our study suggests that anthropogenic activities have significantly changed the hydrological characteristics of the studied area and that this can accelerate carbon loss from the riparian wetlands and further influence GHG emissions in the future.

Data availability. All relevant data are included as graphics and tables in the paper. All raw data will be made available on request.

Author contributions. XinL, XixL, and RY designed the research framework and wrote the manuscript. XXL and RHY supervised the study. XinL, HX, ZQ, ZC, and ZZ carried out the field experiments and laboratory analyses. ZZ drew the GIS mapping in this paper. TL proofread a previous version of the manuscript. HS contributed much to the revised version of our manuscript.

Competing interests. The authors declare that they have no conflict of interest.

Disclaimer. Publisher's note: Copernicus Publications remains neutral with regard to jurisdictional claims in published maps and institutional affiliations.

Acknowledgements. This study was funded by the National Key Research and Development Program of China (grant no. 2016YFC0500508), Major Science and Technology Projects of Inner Mongolia Autonomous Region (grant nos. 2020ZD0009 and ZDZX2018054), National Natural Science Foundation of China (grant no. 51869014), Key Scientific and Technological Project of Inner Mongolia (grant no. 2019GG019), and Open Project Program of the Ministry of Education Key Laboratory of Ecology and Resources Use of the Mongolian Plateau (grant no. KF2020006). We thank Wiley Editing Services (http://wileyeditingservices.com, last access: 24 June 2021) for its linguistic assistance during the preparation of a previous version of this paper.

Financial support. This research has been supported by the National Key Research and Development Program of China (grant no. 2016YFC0500508), the National Natural Science Foundation of China (grant no. 51869014), the Science and Technology Major Project on Lakes of Inner Mongolia (grant nos. 2020ZD0009 and ZDZX2018054), Key Scientific and Technological Project of Inner Mongolia (grant no. 2019GG019), and Open Project Program of the Ministry of Education Key Laboratory of Ecology and Resources Use of the Mongolian Plateau (grant no. KF2020006).

Review statement. This paper was edited by Anja Rammig and reviewed by two anonymous referees.

\section{References}

Azam, F., Gill, S., and Farooq, S.: Availability of $\mathrm{CO}_{2}$ as a factor affecting the rate of nitrification in soil, Soil Biol. Biochem., 37, 2141-2144, https://doi.org/10.1016/j.soilbio.2005.02.036, 2005.

Baggs, E. M., Richter, M., Cadisch, G., and Hartwig, U. A.: Denitrification in grass swards is increased under elevated atmospheric $\mathrm{CO}_{2}$, Soil Biol. Biochem., 35, 729-732, https://doi.org/10.1016/S0038-0717(03)00083-X, 2003.

Beger, M., Grantham, H. S., Pressey, R. L., Wilson, K. A., Peterson, E. L., Dorfman, D., Lourival, R., Brumbaugh, D. R., and Possingham, H. P.: Conservation planning for connectivity across marine, freshwater, and terrestrial realms, Biol. Conserv., 143, 565575, https://doi.org/10.1016/j.biocon.2009.11.006, 2010.

Brady, N. C.: Nature and properties of soils, Prenflee-Hall, Inc., Wichita, USA, https://doi.org/10.2307/3894608, 1999.

Cao, M., Yu, G., Liu, J., and Li, K.: Multi-scale observation and cross-scale mechanistic modelling on terrestrial ecosystem carbon cycle, Sci. China Ser. D, 48, 17-32, 2005.

Chao, R.: Effects of Simulated Climate Change on Greenhouse Gas Fluxes in Typical Steppe Ecosystem, MS thesis, Inner Mongolia University, Hohhot, China, 2019.

Cheng, S. and Huang, J.: Enhanced soil moisture drying in transitional regions under a warming climate, J. Geophys. Res.-Atmos., 121, 2542-2555, https://doi.org/10.1002/2015JD024559, 2016.

Christensen, S., Simkins, S., and Tiedje, J. M.: Temporal Patterns of Soil Denitrification: Their Stability and Causes, Soil Sci. Soc. Am. J., 54, 1614, https://doi.org/10.2136/sssaj1990.03615995005400060017x, 1990.

Ding, W., Cai, Z., and Tsuruta, H.: Cultivation, nitrogen fertilization, and set-aside effects on methane uptake in a drained marsh soil in Northeast China, Glob. Change Biol., 10, 1801-1809, https://doi.org/10.1111/j.1365-2486.2004.00843.x, 2010. 
Enwall, K., Philippot, L., and Hallin, S.: Activity and composition of the denitrifying bacterial community respond differently to long-term fertilization, Appl. Environ. Microb., 71, 8335-8343, https://doi.org/10.1128/AEM.71.12.8335-8343.2005, 2005.

Fan, X.: Research on nitrification potential and denitrification potential of soil in several farmland in China, Nanjing Institute of Soil Sciences, PhD thesis, Chinese Academy of Sciences, Nanjing, China, 1995.

Ferrón, S., Ortega, T., Gómez-Parra, A., and Forja, J. M.: Seasonal study of dissolved $\mathrm{CH}_{4}, \mathrm{CO}_{2}$ and $\mathrm{N}_{2} \mathrm{O}$ in a shallow tidal system of the bay of Cádiz (SW Spain), J. Marine Syst., 66, 244-257, https://doi.org/10.1016/j.jmarsys.2006.03.021, 2007.

Geng, H.: Study on Charactors of $\mathrm{CO}_{2}, \mathrm{CH}_{4}, \mathrm{~N}_{2} \mathrm{O}$ Fluxes and the Relationship between Them and Environmental Factors in the Temperate Typical Grassland Ecosystem, MS thesis, Northwest Agriculture \& Forestry University, Yangling, China, 2004.

Gholz, H. L., Wedin, D. A., Smitherman, S. M., Harmon, M. E., and Parton, W. J.: Long-term dynamics of pine and hardwood litter in contrasting environments: toward a global model of decomposition, Glob. Change Biol., 6, 751-765, https://doi.org/10.1046/j.1365-2486.2000.00349.x, 2000.

Gou, Q., Qu, J., Wang, G., Xiao, J., and Pang, Y.: Progress of wetland researches in arid and semi-ariregions in China, Arid Zone Research, 32, 213-220, 2015.

Guo, X., Zhou, D., and Li, Y.: Net Greenhouse Gas Emission and Its Influencing Factors in Inner Mongolia Grassland, Chinese Grassland Society, Guangzhou, China, 2017.

Heilman, J. L., Cobos, D. R., Heinsch, F. A., Campbell, C. S., and McInnes, K. J.: Tower-based conditional sampling for measuring ecosystem-scale carbon dioxide exchange in coastal wetlands, Estuaries, 22, 584-591, https://doi.org/10.2307/1353046, 1999.

Hui, R. N.: Study on the emission of $\mathrm{CO}_{2}$ and its impact factors in riparian wetland, MS thesis, Northeast Forestry University, 23 pp., 2014.

Inubushi, K., Furukawa, Y., Hadi, A., Purnomo, E., and Tsuruta, $\mathrm{H}$.: Seasonal changes of $\mathrm{CO}_{2}, \mathrm{CH}_{4}$ and $\mathrm{N}_{2} \mathrm{O}$ fluxes in relation to land-use change in tropical peatlands located in coastal area of South Kalimantan, Chemosphere, 52, 603-608, https://doi.org/10.1016/s0045-6535(03)00242-x, 2003.

IPCC: Climate Change 2013: The Physical Science Basis. Contribution of Working, Working Group I of the IPCC, 43, 866-871, 2013.

Jacinthe, P. A., Vidon, P., Fisher, K., Liu, X., and Baker, M. E.: Soil Methane and Carbon Dioxide Fluxes from Cropland and Riparian Buffers in Different Hydrogeomorphic Settings, J. Environ. Qual., 44, 1080-1115, https://doi.org/10.2134/jeq2015.01.0014, 2015.

Johnson-Randall, L. A. and Foote, A. L.: Effects of managed impoundments and herbivory on wetland plant production and stand structure, Wetlands, 25, 38-50, https://doi.org/10.1672/02775212(2005)025[0038:EOMIAH]2.0.CO;2, 2005.

Koops, J. G., Oenema, O., and Beusichem, M. L.: Denitrification in the top and sub soil of grassland on peat soils, Plant Soil, 184, 1-10, https://doi.org/10.1007/bf00029269, 1996.

Kou, X.: Study on Soil Physicochemical Properties and Bacterial Community Characteristics of River Riparian Wetland in Inner Mongolia Grassland, MS thesis, Inner Mongolia University, Hohhot, China, 2018.
Liu, C.: Effects of Nitrogen Addition on the $\mathrm{CO}_{2}$ Emissions in the Reed (Phragmites australis) Wetland of the Yellow River Delta, China, MS thesis, Liaocheng University, Liaocheng, China, 2019.

Liu, C., Xie, G., and Huang, H.: Shrinking and drying up of Baiyangdian Lake wetland: a natural or human cause?, Chinese Geogr. Sci., 16, 314-319, 2006.

Liu, F., Liu, C., Wang, S., and Zhu, Z.: Correlations among $\mathrm{CO}_{2}, \mathrm{CH}_{4}$, and $\mathrm{N}_{2} \mathrm{O}$ concentrations in soil profiles in central Guizhou Karst area, Chinese Journal of Ecology, 29, 717-723, https://doi.org/10.1016/S1872-5813(11)60001-7, 2010.

Liu, J., Wang, J., Li, Z., Yu, J., Zhang, X., Wang, C., and Wang, Y.: $\mathrm{N}_{2} \mathrm{O}$ Concentration and Its Emission Characteristics in Sanjiang Plain Wetland, Chinese Journal of Environmental Science, 24, 33-39, 2003.

$\mathrm{Lu}$, Y., Song, C., Wang, Y., and Zhao, Z.: Influence of plants on $\mathrm{CO}_{2}$ and $\mathrm{CH}_{4}$ emission in wetland ecosystem, Acta Botanica BorealiOccidentalia Sinica, 27, 2306-2313, 2007.

Lu, Z., Du, R., Du, P., Li, Z., Liang, Z., Wang, Y., Qin, S., and Zhong, L.: Effect of mowing on $\mathrm{N}_{2} \mathrm{O}$ and $\mathrm{CH}_{4}$ fluxes emissions from the meadow-steppe grasslands of Inner Mongolia, Front. Earth Sci., 9, 473-486, https://doi.org/10.1007/s11707014-0486-z, 2015.

Lv, M., Sheng, L., and Zhang, L.: A review on carbon fluxes for typical wetlands in different climates of China, Wetland Science, 11, 114-120, https://doi.org/10.13248/j.cnki.wetlandsci.2013.01.001, 2013.

Malhl, S. S. and Mcgill, W. B.: Nitrification in three Alberta soils: effects of temperature, moisure and substrates concentration, Soil Biol. Biochem., 14, 393-399, https://doi.org/10.1016/00380717(82)90011-6, 1982.

Mclain, J. E. T. and Martens, D. A.: Moisture controls on trace gas fluxes in semiarid riparian soils, Soil Sci. Soc. Am. J., 70, 367, https://doi.org/10.2136/sssaj2005.0105, 2006.

Meng, W., Wu, D., and Wang, Z.: Control factors and critical conditions between carbon sinking and sourcing of wetland ecosystem, Ecology and Environmental Sciences, 20, 13591366, https://doi.org/10.1016/S1671-2927(11)60313-1, 2011.

Mitsch, W. J. and Gosselink, J. G.: Wetlands (Fourth Edition), John Wiley \& Sons Inc., Hoboken, NJ, 2007.

Mitsch, W. J., Gosselink, J. G., Zhang, L., and Anderson, C. J.: Wetland ecosystems, John Wiley \& Sons, New Jersey, USA, 2009.

Moldrup, P., Olesen, T., Schjønning, P., Yamaguchi, T., and Rolston, D. E.: Predicting the gas diffusion coefficient in undisturbed soil from soil water characteristics, Soil Sci. Soc. Am. J., 64, 15881594, https://doi.org/10.2136/sssaj2000.64194x, 2000.

Morley, N. and Baggs, E. M.: Carbon and oxygen controls on $\mathrm{N}_{2} \mathrm{O}$ and $\mathrm{N}_{2}$ production during nitrate reduction, Soil Biol. Biochem., 42, 1864-1871, https://doi.org/10.1016/j.soilbio.2010.07.008, 2010.

Naiman, R. J. and Decamps, H.: The ecology of interfaces: Riparian zones, Annu. Rev. Ecol. Syst., 28, 621-658, https://doi.org/10.1146/annurev.ecolsys.28.1.621, 1997.

National Agricultural Technology Extension Service Center (NATESC): Technical specification for soil analysis, China Agriculture Press, Beijing, China, 256 pp., ISBN 978-71-0910-925-9, 2006.

Niu, C., Wang, S., Guo, Y., Liu, W., and Zhang, J.: Studies on variation characteristics of soil nitrogen forms, nitrous oxide emis- 
sion and nitrogen storage of the Phragmites australis-dominated land/inland water ecotones in Baiyangdian wetland, Journal of Agricultural University of Hebei, 40, 72-79, 2017.

Pierzynski, G. M., Vance, G. F., and Sims, T. J.: Soils and Environmental Quality, 3rd Edn., CRC Press Inc., Boca Raton, 592 pp., https://doi.org/10.1201/b12786, 2005.

Poblador, S., Lupon, A., Sabaté, S., and Sabater, F.: Soil water content drives spatiotemporal patterns of $\mathrm{CO}_{2}$ and $\mathrm{N}_{2} \mathrm{O}$ emissions from a Mediterranean riparian forest soil, Biogeosciences, 14, 4195-4208, https://doi.org/10.5194/bg-14-4195-2017, 2017.

Qin, S., Tang, J., Pu, J., Xu, Y., Dong, P., Jiao, L., and Guo, J.: Fluxes and influencing factors of $\mathrm{CO}_{2}$ and $\mathrm{CH}_{4}$ in Hangzhou Xixi Wetland, China, Earth and Environment, 44, 513-519, 2016.

Rückauf, U., Augustin, J., Russow, R., and Merbach, W.: Nitrate removal from drained and reflooded fen soils affected by soil $\mathrm{N}$ transformation processes and plant uptake, Soil Biol. Biochem., 36, 77-90, https://doi.org/10.1016/j.soilbio.2003.08.021, 2004.

Sjögersten, S., Wal, R. V. D., and Woodin, S. J.: Smallscale hydrological variation determines landscape $\mathrm{CO}_{2}$ fluxes in the high Arctic, Biogeochemistry, 80, 205-216, https://doi.org/10.1007/s10533-006-9018-6, 2006.

Sun, Y., Wu, H., and Wang, Y.: The influence factors on $\mathrm{N}_{2} \mathrm{O}$ emissions from nirification and denitrification reaction, Ecology and Environmental Sciences, 20, 384-388, https://doi.org/10.1631/jzus.B1000275, 2011.

Tong, C., Wu, J., Yong, S., Yang, J., and Yong, W.: A landscapescale assessment of steppe degradation in the Xilin River Basin, Inner Mongolia, China, J. Arid Environ., 59, 133-149, https://doi.org/10.1016/j.jaridenv.2004.01.004, 2004.

Waddington, J. M. and Roulet, N. T.: Carbon balance of a boreal patterned peatland, Glob. Change Biol., 6, 87-97, https://doi.org/10.1046/j.1365-2486.2000.00283.x, 2000.

Whiting, G. J. and Chanton, J. P.: Greenhouse earbon balance of wetlands: methane emission versus carbon sequestration, Tellus B, 53, 521-528, https://doi.org/10.3402/tellusb.v53i5.16628, 2001.

WMO: WMO Statement on the State of the Global Climate in 2017, World Meteorological Organization, 2018.
Xi, X., Zhu, Z., and Hao, X.: Spatial variability of soil organic carbon in Xilin River Basin, Research of Soil and Water Conservation, 24, 97-104, 2017.

Xia, P., Yu, L., Kou, Y., Deng, H., and Liu, J.: Distribution characteristics of soil organic carbon and its relationship with enzyme activity in the Caohai wetland of the Guizhou Plateau, Acta Scientiae Circumstantial, 37, 1479-1485, https://doi.org/10.13671/j.hjkxxb.2016.0129, 2017.

Xu, H., Cai, Z., and Yagi, K.: Methane Production Potentials of Rice Paddy Soils and Its Affecting Factors, Acta Pedologica Sinica, 45, 98-104, https://doi.org/10.1163/156939308783122788, 2008.

Yan, L., Zhang, X., Wang, J., Li, Y., Wu, H., and Kang, X.: Drainage effects on carbon flux and carbon storage in swamps, marshes, and peatlands, Chin. J. Appl. Environ. Biol., 24, 1023-1031, https://doi.org/10.19675/j.cnki.1006-687x.2017.11031, 2018.

$\mathrm{Yu}$, P., Zhang, J., and Lin, C.: Progress of influence factors on $\mathrm{N}_{2} \mathrm{O}$ emission in farmland soil, Environment and sustainable development, 5, 20-22, 2006.

Zhang, D.: Effects of Different Grazing Intensities on Greenhouse Gases Flux in Typical Steppe of Inner Mongolia, MS thesis, Inner Mongolia University, Hohhot, China, 2019.

Zhang, Y., Hao, Y., Cui, L., Li, W., Zhang, X., Zhang, M., Li, L., Yang, S., and Kang, X.: Effects of extreme drought on $\mathrm{CO}_{2}$ fluxes of Zoige alpine peatland, Journal of University of Chinese Academy of Sciences, 34, 462-470, 2017.

Zhang, Z., Hua, L., Yin, X., Hua, L., and Gao, J.: Nitrous oxide emission from agricultural soil land some influence factors, Journal of Capital Normal University: Natural Science Edition, 26, 114-120, 2005.

Zhu, X., Song, C., Guo, Y., Shi, F., and Wang, L.: $\mathrm{N}_{2} \mathrm{O}$ emissions and its controlling factors from the peatlands in the Sanjiang Plain, China Environmental Sciences, 33, 2228-2234, 2013.

Zona, D., Oechel, W. C., Kochendorfer, J., Paw, U. K. T., Salyuk, A. N., Olivas, P. C., Oberbauer, S. F., and Lipson, D. A.: Methane fluxes during the initiation of a large-scale water table manipulation experiment in the Alaskan Arctic tundra, Global Biogeochem. Cy., 23, GB2013, https://doi.org/10.1029/2009gb003487, 2009. 